\begin{tabular}{|c|l|}
\hline Title & $\begin{array}{l}\text { Temporal variability and bioavailability of iron and other nutrients during the spring phytoplankton bloom in the } \\
\text { Oyashio region }\end{array}$ \\
\hline Author(s) & Nakayama, Y uta; Kuma, Kenshi; Fujita, Satoshi; Sugie, Koji; Ikeda, Tsutomu \\
\hline Citation & $\begin{array}{l}\text { Deep Sea Research Part II: Topical Studies in Oceanography, 57(17-18), 1618 1629 } \\
\text { https://doi.org/10.1016/.dsr2.2010.03.006 }\end{array}$ \\
\hline Issue Date & 2010-09 \\
\hline Doc URL & http://hdl.handle.net/2115/43805 \\
\hline Type & article(author version) \\
\hline File Information & DSR2-57-17-18_1618-1629.pdf \\
\hline
\end{tabular}

Instructions for use 
Deep-Sea Res. II

\title{
Temporal variability and bioavailability of iron and other nutrients during the spring phytoplankton bloom in the Oyashio region
}

\author{
Yuta Nakayama ${ }^{\text {a }}$, Kenshi Kuma ${ }^{\text {a, b, }}$, , Satoshi Fujita ${ }^{\text {a }}$, Koji Sugie ${ }^{\text {a }}$, Tsutomu Ikeda ${ }^{\text {b }}$ \\ ${ }^{a}$ Graduate School of Environmental Science, Hokkaido University, Sapporo, Hokkaido \\ 060-0810, Japan \\ ${ }^{\mathrm{b}}$ Faculty of Fisheries Sciences, Hokkaido University, Hakodate, Hokkaido 041-8611, \\ Japan
}

*Corresponding author: Kenshi Kuma, Graduate School of Environmental Science/

Faculty of Fisheries Sciences, Hokkaido University, Kita 10-Nishi 5, Kita-ku, Sapporo,

Hokkaido 060-0810, Japan

Tel \& Fax: +81-11-706-2324

E-mail: kuma@fish.hokudai.ac.jp 


\section{Abstract}

Iron [dissolved Fe (D-Fe) and total dissolvable Fe (T-Fe)] and nutrient concentrations in the surface water of the Oyashio region (northwestern North Pacific) were measured before and during spring phytoplankton bloom (March to May in 2007). During the pre-bloom period (middle of March), we observed vertically uniform concentrations of iron (0.3-0.5 nM [D-Fe] and 3-5 nM [T-Fe]), macronutrients (10-15 $\mu \mathrm{M} \mathrm{NO}_{3}+\mathrm{NO}_{2}$,

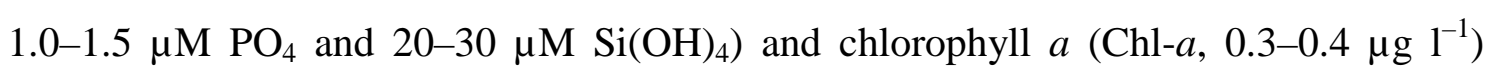
throughout the upper 125 to $150 \mathrm{~m}$ due to vertical mixing during winter. Water temperature and salinity before the bloom were also vertically uniform with $>5^{\circ} \mathrm{C}$ and $\mathrm{S}>33.5$, the conditions of a modified Kuroshio warm-water (MKW) ring, higher than those of the Coastal Oyashio Water (COW). The cold COW $\left(<2^{\circ} \mathrm{C}, \mathrm{S}<33.2\right)$ intruded a few times into the surface during the bloom period with high iron (0.4-0.6 nM [D-Fe] and 10-25 nM [T-Fe]) and Chl- $a\left(10-23 \mu \mathrm{g} \mathrm{l}^{-1}\right)$ concentrations. The high Chl- $a$ observed in the COW is due to the higher original concentrations of iron and macronutrients in the COW than in the MKW. An incubation experiment conducted during a COW intrusion in early April resulted in robust phytoplankton growth and complete exhaustion of nutrients, indicating an adequate supply of bioavailable iron. This result is also consistent with robust in situ phytoplankton growth and Chl- $a$ production due to the presence of high iron levels in the COW. The most important mechanisms transporting iron to the surface water, which would regulate the primary production during spring bloom in the Oyashio region, are the surface intrusions of iron- and nutrient-rich COW derived from vertical and lateral mixing processes and vertical mixing in MKW during winter and spring.

Keywords: Iron; Nutrient; Spring phytoplankton bloom; Vertical water mixing; Coastal Oyashio Water; Oyashio region; Northwestern North Pacific 


\section{Introduction}

Many studies over a few decades have revealed that iron is an essential micronutrient for marine phytoplankton growth because it is an important component of several biochemical processes (Geider and La Roche, 1994). Acquisition of iron by phytoplankton is strongly influenced by iron chemistry and speciation in seawater. Iron in oxic seawater is present as the thermodynamically stable $3+$ oxidation state, primarily as sparingly soluble ferric hydroxides and oxides (Kuma et al., 1996; Stumm and Morgan,1996; Waite, 2001). The iron uptake rate of phytoplankton is generally related to the computed equilibrium concentration of $\mathrm{Fe}^{3+}$ in seawater and is actually dependent on the concentration of dissolved inorganic $\mathrm{Fe}(\mathrm{III})$ species ([Fe(III)']), which is proportional to $\left[\mathrm{Fe}^{3+}\right.$ ] (Anderson and Morel, 1982; Campbell, 1995; Sunda, 2001) although apparent exceptions to the model exist. For example, specific transport ligands such as siderophores may be indirectly utilized by cells (Hutchins et al., 1999; Sunda, 2001), and a new model recently proposed by Shaked et al. (2005) for iron uptake by diatoms in which extracellular reduction of all Fe species is a necessary step for iron acquisition. The most bioavailable iron species are Fe(III)' and dissolved inorganic $\mathrm{Fe}(\mathrm{II})$ species (Fe(II)') that are produced from in situ $\mathrm{Fe}(\mathrm{III})$ reduction. Phytoplankton can also acquire iron from dissolved iron chelates, but these chemical species are orders of magnitude less available than Fe(III)'. The availability of these species varies inversely with the stability of the complexes so that the availability of iron chelated with certain stable siderophores (e.g. desferrioxamine B: DFB) is very low, but is still finite. Therefore, the $\mathrm{Fe}(\mathrm{III})^{\prime}$ solubility and dissolution rate of solid $\mathrm{Fe}(\mathrm{III})$ hydroxide in seawater limit the iron uptake of phytoplankton if the dissolution rate is slow in relation to the demands of the phytoplankton. However, higher concentration of solid Fe(III) hydroxide will sustain a higher iron uptake rate in phytoplankton through the increase in $\mathrm{Fe}(\mathrm{III})^{\prime}$ dissolution rate, resulting from the increasing surface area in proportion to the concentration of solid Fe(III) hydroxide (Kuma and Matsunaga, 1995; Yoshida et al., 2006).

It has been shown that iron limits phytoplankton biomass, growth rate, species composition and primary production in oceanic regions. Atmospheric input and upwelling are the major source of Fe to remote oceanic surface waters (Coale et al., 1996). Coastal ecosystems are in close proximity to terrestrial and continental shelf 
sources of iron. In addition, it seems that the coastal Fe distributions are highly dependent on local bathymetry and physical mechanisms. Many studies of iron in coastal regions have shown that iron is supplied to surface water by upwelling, vertical water mixing, atmospheric and riverine inputs (de Baar and de Jong, 2001; Hutchins et al., 1998; Jickells and Spokes, 2001; Kuma et al., 2000; Bruland et al., 2001; Nishioka et al., 2007; Saitoh et al., 2008). The supply of the micronutrient iron, relative to that of macronutrients, plays a critical role in generating the extensive phytoplankton blooms of coastal regions (Hutchins et al., 1999; Wells, 1999; Bruland et al., 2001). Recently, it has been reported that iron supplied from shelf sediments to the surface water in coastal upwelling systems induces high phytoplankton biomass, primary productivity and macronutrient drawdown over the California continental shelf (Fitzwater et al., 2003; Chase et al., 2005). However, the transport mechanisms and the magnitudes of the various sources in the coastal iron cycles are not well known.

In the OECOS-WEST program, we conducted intensive sampling for the vertical changes of iron, macronutrients, chlorophyll $a$ (Chl-a) and hydrographic data before and during spring phytoplankton bloom (March to April in 2007) at a fixed station (Stn A-5, Fig. 1) in the Oyashio region (near Hokkaido Island, Japan), which has complex water mass exchanges, in order to assess the possible iron and macronutrient inputs and pathways and the geochemical and physical processes (Kono and Sato; Sato and Kono, this issue) regulating primary production during the bloom in different dominant water masses. Initiation and seasonal timing of the spring bloom in the Oyashio region were also investigated by satellite imagery and Argo float data (Okamoto et al., this issue).

The hydrography in the Oyashio region is often complex, with two or three dominant water masses with different chemical and physical properties moving through during spring (Kono and Sato, this issue). The westward flowing "Oyashio Water" (OYW, subarctic water), characterized by low temperature and low salinity, flows along the Pacific Ocean side of Hokkaido. The Oyashio Water (OYW) is considered to be formed by mixing of Okhotsk Sea water and Western Subarctic water near the Kuril Islands (Kono and Kawasaki, 1997). OYW is carried to the Pacific Ocean side of Hokkaido by the Oyashio Current, which is a western boundary current of the Western Subarctic Gyre in the North Pacific, with marked seasonal variation but having the most intensive and directionally stable flow during winter (Uehara et al., 1997). Cold, low 
salinity water, called "Coastal Oyashio Water" (COW), appears in the surface layer on the onshore side of the OYW during spring as a southwestward flow along the east cost of Hokkaido after coming through the passes of the southern Kuril islands (Hanawa and Mitsudera, 1986; Oguma et al., 2008; Kono and Sato, this issue). In addition, "modified Kuroshio warm-water rings" (MKW), which detach from the Kuroshio Extension, are frequently found in the Oyashio region (Yasuda et al., 1992). In our OECOS-WEST program, it is suggested that the fraction of COW among COW, OYW and MKW was significantly correlated with Chl- $a$ concentration in the surface water due to the advection and diffusion of COW (Kono and Sato, this issue). In the present study, we investigated the vertical changes of iron and macronutrients, which are important chemical components in inducing the spring bloom and supporting high phytoplankton growth rate before and during the bloom in the Oyashio region.

\section{Materials and methods}

\subsection{Sample collection and treatment}

Seawater samples were collected at depths from 5 to 300-m at one station (Stn A-5: $42^{\circ} 00^{\prime} \mathrm{N}, 145^{\circ} 15^{\prime} \mathrm{E}$ ) in the Oyashio region of the western North Pacific Ocean during 9-14 March (before spring phytoplankton bloom) and during 5 April-1 May (the spring bloom period) in 2007 (Fig. 1). We used acid-cleaned, Teflon-coated, 10-liter Niskin X sampling bottles (General Oceanics) attached to a CTD-RMS. Sample filtration for analyses of dissolved $\mathrm{Fe}$ (D-Fe) was carried out by connecting an acid-cleaned 0.22- $\mu \mathrm{m}$ pore size Durapore membrane filter (Cartridge type-Millipak 100, Millipore) to a sampling bottle spigot and then filtering by hydrostatic pressure from the bottle. Unfiltered samples were collected for total dissolvable Fe (T-Fe), chlorophyll a (Chl-a) and nutrient concentrations. The filtered and unfiltered seawater (100 $\mathrm{ml}$ in precleaned 125-ml LDPE) used for D-Fe $(<0.22-\mu \mathrm{m}$ fraction) and T-Fe (unfiltered) analyses were buffered at $\mathrm{pH} 3.2$ with $10 \mathrm{M}$ formic acid-2.4 M ammonium formate solution ( $0.5 \mathrm{ml}$ per $100-\mathrm{ml}$ sample solution) in a class 100 clean-air bench on board as soon as the samples were collected. The buffered samples ( $\mathrm{pH} 3.2)$ were kept at room temperature for 3-4 months for D-Fe and for 6 months at least for T-Fe until iron 
analysis in the laboratory. Hydrographic observations (salinity, temperature and depth) were conducted with a CTD (Conductivity Temperature Depth probe).

\subsection{Dissolved Fe, total dissolvable Fe, nutrient and chlorophyll a concentrations}

The iron concentrations (dissolved Fe: [D-Fe]; total dissolvable Fe: [T-Fe]) in buffered 0.22- $\mu \mathrm{m}$ filtered and unfiltered samples were determined by an automated Fe analyzer (Kimoto Electric Co. Ltd.) by use of a combination of chelating resin concentration and luminol-hydrogen peroxide chemiluminescence (CL) detection in a closed flow-through system (Obata et al., 1993) as reported in our previous studies (Takata et al., 2004, 2005, 2006, 2008). Briefly, iron in a buffered sample solution was selectively collected on 8-hydroxyquinoline immobilized chelating resin and then eluted with dilute $0.3 \mathrm{~N} \mathrm{HCl}$. The eluent was mixed with luminol solution, $0.6 \mathrm{~N}$ aqueous ammonia and $0.7 \mathrm{M} \mathrm{H}_{2} \mathrm{O}_{2}$ solution successively, and then the mixture was introduced into the CL cell. Finally, the iron concentration was determined from the CL intensity. The weak acidification of unfiltered seawater samples may lead to inclusion of a fraction of the acid leachable particulate Fe (P-Fe) as well as D-Fe iron. Accuracy of this analysis was checked using the SAFe reference materials (S1 and D2 solutions, $\mathrm{pH}$ 1.7-1.8). The SAFe reference materials were found to be within the range of the consensus values: $0.097 \pm 0.043 \mathrm{nM}$ for $\mathrm{S} 1$ and $0.91 \pm 0.17 \mathrm{nM}$ for D2 (Johnson et al., 2007). The [D-Fe] of S1 and D2 reference samples, which were determined by our analytical method after being buffered at $\mathrm{pH} 3.2$ in the present study, were $0.113 \pm 0.004$ $\mathrm{nM}$ and $0.99 \pm 0.09 \mathrm{nM}$, both within the ranges of the consensus values.

Major nutrient concentrations in seawater were determined using a QuAAtro (Bran+Luebbe) analyzer. The concentrations of Chl- $a$ were determined by the fluorometric method (Tuner Designs 10-AU) after N, N-dimethylformamide extraction (Suzuki and Ishimaru, 1990).

\subsection{Shipboard culture experiments}

Shipboard incubations of the phytoplankton community were conducted using the surface water in the Oyashio region of the northwestern North Pacific Ocean. 
Near-surface seawater (10 m depth) was collected on 6 April 2007 during the spring phytoplankton bloom in COW (low temperature of $1.70^{\circ} \mathrm{C}$ and low salinity of 33.04) at $42^{\circ} 03^{\prime} \mathrm{N}$ and $145^{\circ} 15^{\prime} \mathrm{E}$ using acid-cleaned, Teflon-coated, 10 -liter Niskin X sampling bottles (General Oceanics) attached to a CTD-RMS (Takata et al., 2006). The Fe concentrations in the filtered and unfiltered natural Iseawater used in the shipboard incubations were determined by an automated Fe analyzer (Kimoto Electric) as described above.

After passing the seawater through a $100-\mu \mathrm{m}$ acid-cleaned Teflon-mesh to eliminate large herbivorous zooplankton, the seawater sample was homogenized in a 20-liter acid-washed polyethylene tank and dispensed immediately into $250 \mathrm{ml}$ acid-washed polycarbonate incubation bottles. We examined the potential of the natural phytoplankton community (dominantly large chain-forming diatoms, Sugie et al., this issue) to grow using intracellularly stored Fe with only addition of the siderophore desferrioxamine B (DFB) to this surface seawater with relatively high iron and nutrient concentrations in the incubation bottles (DFB treatment). It has been reported that the addition of excess concentrations of DFB essentially eliminated iron uptake in a picoplankton-dominated community by diminishing the concentration of bioavailable iron species (Wells et al., 1994) and by regulating iron availability in coastal upwelling waters (Hutchins et al., 1999; Wells, 1999). DFB is a small trihydroxamate molecule that complexes inorganic Fe(III) with an extremely high conditional stability constant $\left(K_{\mathrm{FeL}, \mathrm{Fe}(\mathrm{III})}^{\prime}=[\mathrm{Fe}(\mathrm{III}) \mathrm{L}] /\left[\mathrm{Fe}(\mathrm{III})^{\prime}\right]\left[\mathrm{L}^{\prime}\right]=10^{16.5} \mathrm{M}^{-1}\right.$; Hudson et al., 1992). Recent culture experiments regulating iron availability by the addition of DFB have revealed that the high growth rate of coastal diatoms (Chaetoceros sociale and Thalassiosira weissflogii) is maintained for a few days even after the addition of DFB, which prevents further uptake of ambient extracellular Fe in the medium, due to the intracellularly stored Fe (Iwade et al., 2006; Yoshida et al., 2006). The final DFB concentration was $1 \mu \mathrm{mol} \mathrm{l} \mathrm{l}^{-1}$. Control (without any added iron, nutrient or DFB) was prepared to compare the growth with ambient iron available in the collected seawater. Incubations were done at $5^{\circ} \mathrm{C}$ in an incubator under $150 \mu \mathrm{mol}$ photons $\mathrm{m}^{-2} \mathrm{~s}^{-1}$ fluorescent light (12h light: $12 \mathrm{~h}$ dark) for 5 days. Culture experiments were conducted in triplicate (three incubation bottles for each treatment at each time-point (1, 3 and 5 day)). Chl- $a$ concentrations initially and after 1,3 and 5 d cultivations were determined by the method described above. All 
preparations for these experiments were performed in a clean room or clean bench (Class 100) on board. The nutrient concentrations in the seawater samples during shipboard incubation were measured with a QuAAtro (Bran+Luebbe) analyzer.

\section{Results}

3.1. Hydrographic conditions before and during the spring bloom in 2007 at Stn A-5 in the Oyashio region

Figure 2 shows the vertical sections of temperature $\left[{ }^{\circ} \mathrm{C},(\mathrm{a})\right]$ and salinity [psu, (b)] at Stn A-5 on 8-14 March (before the spring phytoplankton bloom) and 5 April-1 May (during the bloom) in 2007 at Stn A-5. The vertical variations of temperature and salinity on 8-14 March before the spring bloom revealed a warm water mass with almost homogeneous high temperature $\left(\sim 5-6^{\circ} \mathrm{C}\right)$ and high salinity $(>33.5)$ throughout the upper 125-150 m of the water column, which probably originated from the modified Kuroshio Water (MKW). Similarly warm water was also observed in the upper 50-75 m on 13-19 April during the bloom. However, the intrusion of cold water with low temperature $\left(1-2^{\circ} \mathrm{C}\right)$ and low salinity $(<33.2)$ was observed in the upper $40-100 \mathrm{~m}$ on 6-8 April and the upper $50 \mathrm{~m}$ on 23-25 April during the bloom.

3.2. Variations of iron, Chl-a and nutrient concentrations before and during the spring bloom in 2007 at Stn A-5

Figure 3 shows the vertical sections of Chl- $a$ concentration (a), $\mathrm{NO}_{3}+\mathrm{NO}_{2}$ concentration (b), [D-Fe] (c) and [T-Fe] (d) on 9-14 March (before spring bloom) and 5 April-1 May (during the spring bloom) in 2007 at Stn A-5. The concentrations of Chl- $a$, $\mathrm{NO}_{3}+\mathrm{NO}_{2}$, [D-Fe] and [T-Fe] before the bloom were remarkably uniform throughout the upper 125-150 m, similar to the vertically homogeneous distributions of temperature $\left(\sim 5-6^{\circ} \mathrm{C}\right)$ and salinity (>33.5) (Fig. 2). The vertically uniform [D-Fe], [T-Fe] and Chl- $a$ concentration in the surface mixed layer on 10 and 14 March were approximately $\sim 0.3-0.5 \mathrm{nM}, \sim 3-5 \mathrm{nM}$ and 0.3-0.4 $\mu \mathrm{g} \mathrm{l} \mathrm{l}^{-1}$, respectively (Fig. 4a, b and c). Nutrient concentrations were also very uniform at $10-15 \mu \mathrm{M}$ for $\mathrm{NO}_{3}+\mathrm{NO}_{2}, 1-1.5 \mu \mathrm{M}$ 
for $\mathrm{PO}_{4}$ and 20-30 $\mu \mathrm{M}$ for $\mathrm{Si}(\mathrm{OH})_{4}$ within the upper 125-150 m and increased with depth (Fig. 4d, e and f).

During the spring bloom, the iron concentrations in the relatively warm upper $50 \mathrm{~m}$ on 13-19 April decreased to the low ranges of 0.1-0.2 $\mathrm{nM}[\mathrm{D}-\mathrm{Fe}]$ and $\sim 3 \mathrm{nM}$ [T-Fe], corresponding with increased Chl- $a$ concentration $\left(1-3 \mu \mathrm{g} \mathrm{l}^{-1}\right.$ ) (Figs. 3, 5a, b and c) and a small decrease in nutrient concentrations (8-10 $\mu \mathrm{M} \mathrm{NO}_{3}+\mathrm{NO}_{2}, 0.9-1.0 \mu \mathrm{M}$ $\mathrm{PO}_{4}$ and 9-11 $\mu \mathrm{M} \mathrm{Si}(\mathrm{OH})_{4}$, Figs. 3, 5d, e and f). However, the iron and Chl-a concentrations in colder water with lower salinity $(\mathrm{S}<33.1)$ in the upper $10 \mathrm{~m}$ on 6 and 7 April were remarkably high: $0.4-0.7 \mathrm{nM}$ [D-Fe], 16-21 nM [T-Fe] and 14-17 $\mu \mathrm{g} \mathrm{l^{-1 }}$ Chl- $a$ (Figs. 3, 6a, b and c), and there was a sharp decrease in nutrient concentrations (1.7-2.2 $\mu \mathrm{M} \mathrm{NO}_{3}+\mathrm{NO}_{2}, 0.6-0.7 \mu \mathrm{M} \mathrm{PO}_{4}$ and $\left.~ 7.5 \mu \mathrm{M} \mathrm{Si}(\mathrm{OH})_{4}\right)$ on 6 and 7 April (Figs. 3 , 6d, e and f). In addition, the iron and Chl- $a$ concentrations in the cold upper $50 \mathrm{~m}$ layer on 23 and 25 April were relatively high at 0.3-0.5 nM [D-Fe], 4-11 nM [T-Fe] and 3-6 $\mu \mathrm{g} \mathrm{l}^{-1}$ Chl-a (Figs. 3, 7a, b and c) with large decreases in macronutrients (3.5-8.3 $\mu \mathrm{M} \mathrm{NO} \mathrm{NO}_{3}+\mathrm{NO}_{2}, 0.7-1.1 \mu \mathrm{M} \mathrm{PO}_{4}$ and 5.0-8.5 $\left.\mu \mathrm{M} \mathrm{Si}(\mathrm{OH})_{4}\right)$ in the upper $10 \mathrm{~m}$ (Figs. 3, 7d, e and f).

Figure 8 presents the average values of salinity, $\mathrm{NO}_{3}+\mathrm{NO}_{2}$, Chl- $a$, iron concentrations ([D-Fe] and [T-Fe]) in the upper 10-20 m before and during the bloom. High average Chl- $a$ concentrations (Fig. 8b) were found in cold water with low salinity $\left(\mathrm{S}<33.1\right.$, arrow sign in Fig. 8a), which was associated with low $\mathrm{NO}_{3}+\mathrm{NO}_{2}$ concentrations (Fig. 8b) and high iron concentrations (Fig. 8c), especially on 6-8 April. In contrast, low average Chl- $a$ concentrations $\left(<5 \mu \mathrm{g} \mathrm{l}^{-1}\right)$ were observed in warm saline water with high $\mathrm{NO}_{3}+\mathrm{NO}_{2}$ concentrations (around $10 \mu \mathrm{M}$ ) and low iron concentrations (especially, low [T-Fe] $<5 \mathrm{nM}$ ).

\subsection{Growth potential in shipboard culture experiments}

Iron ([D-Fe] and [T-Fe]), macronutrient $\left(\mathrm{NO}_{3}+\mathrm{NO}_{2}, \mathrm{PO}_{4}\right.$ and $\left.\mathrm{Si}(\mathrm{OH})_{4}\right)$ and Chl- $a$ concentrations in cold near-surface water, which was collected on 6 April during the spring bloom in COW, for the shipboard incubations were high: $0.41 \mathrm{nM}, 15.7 \mathrm{nM}$, $20.4 \mu \mathrm{M}, 1.45 \mu \mathrm{M}, 32.3 \mu \mathrm{M}$ and $12.5 \mu \mathrm{g} \mathrm{l^{-1 }}$ respectively. The high iron, nutrient and Chl- $a$ concentrations were probably due to the lateral surface intrusion of a cold, low salinity water mass. We examined the growth of the natural phytoplankton community 
supported by intracellularly stored Fe by adding only DFB to the surface seawater in the incubation bottles just after collection (DFB treatment). In addition, controls (without any added DFB) were incubated to compare phytoplankton growth with extracellular Fe available as well as macronutrients.

The Chl- $a$ concentration of the natural phytoplankton assemblage during the first three days of incubation increased faster in the controls than in the DFB medium. The highest Chl-a concentration after 3 d cultivation was approximately $32 \mu g l^{-1}$ in the

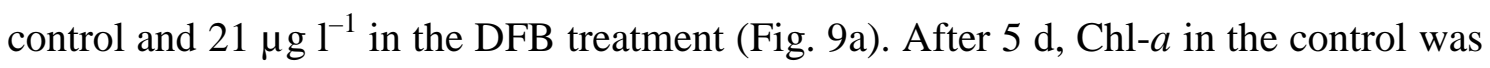
1.5 times higher than that in DFB medium and 2.5 times the initial level $\left(12 \mu \mathrm{g} \mathrm{l}^{-1}\right)$. Macronutrient concentrations in the controls decreased rapidly, nearly to zero at $3 \mathrm{~d}$ for $\mathrm{NO}_{3}+\mathrm{NO}_{2}$ and $\mathrm{Si}(\mathrm{OH})_{4}$ and to $0.25-0.3 \mu \mathrm{M}$ (not likely limiting) at 3-5 $\mathrm{d}$ for $\mathrm{PO}_{4}$. In the DFB treatment, the $\mathrm{NO}_{3}+\mathrm{NO}_{2}$ concentration decreased rapidly, nearly to zero at $3 \mathrm{~d}$ (Fig. 9b), while $\mathrm{PO}_{4}$ and $\mathrm{Si}(\mathrm{OH})_{4}$ concentrations decreased gradually with time to $0.4 \mu \mathrm{M}$ and $3 \mu \mathrm{M}$ at $5 \mathrm{~d}$, respectively (Fig. 9c and d).

\section{Discussion}

4.1. Chemical and biological components in warm water (MKW) and cold water (COW)

The oceanographic regime at Stn A-5 during March-April in 2007 changed dramatically from vertically homogenous warmer water with high salinity (>33.5) before the spring bloom (middle of March) to an intrusion of cold water with low salinity (<33.2), and then again to warm water with high salinity $(>33.5)$ in the surface layer during the bloom (during April). The warmer water $\left(>5^{\circ} \mathrm{C}, \mathrm{S}>33.5\right)$ in the upper 125-150 m before the bloom and the upper 50-75 m during the bloom in mid to late April (Fig. 2) represented a modified Kuroshio water (MKW) ring that had detached from the Kuroshio Extension. It has been reported that warm-water rings are frequently found in the Oyashio region (Yasuda et al., 1992). The MKW before the bloom was vertically homogeneous with uniform concentrations of chemical and biological constituents (iron, major nutrients and Chl-a) and physical parameters (Figs. 2, 3 and 4) throughout the upper 125-150 m due to vertical mixing during winter. The cold waters $\left(<2^{\circ} \mathrm{C}, \mathrm{S}<33.2\right)$ observed in the surface layer during the bloom were probably surface 
intrusions of Coastal Oyashio Water (COW), which appears along the coast of southeastern Hokkaido in winter as a mixture of East Sakhalin Current Water (ESCW) and OYW (Oguma et al., 2008; Kono and Sato, this issue). We estimated the original concentrations of nutrient, D-Fe and T-Fe in the surface mixed layer of MKW and COW during winter due to the vertical mixing of oceanic and coastal waters, respectively. The original concentrations of nutrient in $\mathrm{MKW}$ and COW were roughly estimated as maximal nutrient values near the zero of Chl- $a$ concentration from the relationship between nutrient and Chl- $a$ concentrations in MKW and COW with $\mathrm{S}>33.5$ and $\mathrm{S}<33.3$, respectively. The results are $\sim 10-15 \mu \mathrm{M} \mathrm{NO}_{3}+\mathrm{NO}_{2}, \sim 1-1.5 \mu \mathrm{M} \mathrm{PO}_{4}$ and $\sim 20-30 \mu \mathrm{M}$ $\mathrm{Si}(\mathrm{OH})_{4}$ for $\mathrm{MKW}$ and $\sim 20 \mu \mathrm{M} \mathrm{NO}{ }_{3}+\mathrm{NO}_{2}, \sim 1.8-2 \mu \mathrm{M} \mathrm{PO}_{4}$ and $\sim 40 \mu \mathrm{M} \mathrm{Si}(\mathrm{OH})_{4}$ for COW (Fig. 10). The original concentrations of nutrient in MKW were about one-fourth to one-half of those in COW and were nearly consistent throughout the upper 125-150 $\mathrm{m}$ before the bloom (Fig. 4). It has been reported that the preformed $\mathrm{PO}_{4}$, which is calculated from the relationships between the apparent oxygen utilization (AOU) and $\mathrm{PO}_{4}$, is on the order of $1.6 \mu \mathrm{M}$ in the shallow layer (30-99 m) at Stn knot in the northwestern North Pacific Ocean (Abe, 2002). That is similar to our estimates for pre-bloom levels. In addition, it can be expected that the initial concentrations of nutrients during winter in the shallow layer of the northwestern North Pacific Ocean are the same as the calculated preformed nutrient concentrations because of atmosphere-surface water oxygen equilibration (AOU was assumed to be nearly zero), resulting from the strong winter convection (Abe, 2002). In fact, the preformed $\mathrm{PO}_{4}$ value was nearly consistent with the $\mathrm{PO}_{4}$ concentrations $(1-1.5 \mu \mathrm{M})$ observed in the surface mixed layer (0-125-150 m) during late winter in the present study (Fig. 4). Therefore, nutrients in the surface mixed layer of MKW before the bloom are supplied by vertical mixing during winter, inducing the spring bloom after surface water stabilization. However, nutrients in the surface mixed layer of MKW during the bloom

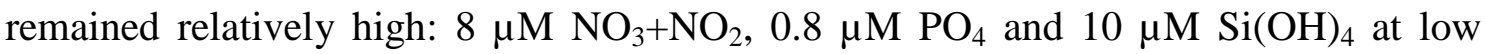
Chl- $a$ concentration ( $3 \mu \mathrm{g} \mathrm{l}^{-1}$ ), probably a result of iron limitation (Figs. 5, 8 and 10). On the other hand, low concentrations of $\mathrm{NO}_{3}+\mathrm{NO}_{2}(<2 \mu \mathrm{M})$ and $\mathrm{Si}(\mathrm{OH})_{4}(<5 \mu \mathrm{M})$ were found at remarkably high Chl- $a$ concentration $\left(>10 \mu \mathrm{g} \mathrm{l}^{-1}\right)$ in the surface water of COW during the bloom (Fig. 10), probably low enough to cause $\mathrm{NO}_{3}+\mathrm{NO}_{2}$ and/or $\mathrm{Si}(\mathrm{OH})_{4}$ limitations rather than iron limitation. This occurred in COW, even though the original nutrient concentrations in COW were 1.3-2 times higher than those in MKW. 
The higher original concentrations of nutrient in COW may be due to the vertical mixing of Okhotsk Sea water during passage through the shallow straits in the southern Kuril islands before mixing with OYW and advection in winter along the coast of southeastern Hokkaido. The original concentrations of D-Fe and T-Fe in the surface mixed layer of MKW were also roughly estimated as minimal iron values at near the zero of Chl- $a$ concentration from the relationships between iron and Chl- $a$ concentrations in MKW (S>33.5), resulting in $~ 0.3-0.4 \mathrm{nM}$ [D-Fe] and $\sim 2-5 \mathrm{nM}$ [T-Fe] (Fig. 11a and b). The estimated original iron concentrations in the surface layer of MKW were nearly consistent with those in the upper 125-150 m before the bloom (Fig. 4). Therefore, iron, as well as nutrient, in the surface of MKW before the bloom is supplied by upward mixing during winter. The supply of iron, rather than macronutrients, to the surface by the vertical mixing of oceanic water would regulate the primary production during the bloom, as indicated by low [D-Fe] and high remaining macronutrient concentrations observed in the surface mixed layer of MKW during the bloom (Fig. 5). In mid-depths below the surface mixed layer of MKW, the similarly downward-increasing vertical profiles of iron and macronutrients (Figs. 4 and 5) suggest that they are controlled by similar biogeochemical and physical processes. The downward increases in [D-Fe] and [T-Fe] are strongly related to the oxidation and remineralization of sinking particulate organic matter. Iron released from microbial decomposition of sinking biogenic organic matter is the primary source for D-Fe in deep waters, and particle scavenging is the major iron removal pathway (Duce and Tindale, 1991; Bruland et al., 1994; Wu and Boyle, 2002). However, macronutrient $\left(\mathrm{NO}_{3}+\mathrm{NO}_{2}\right.$ and $\left.\mathrm{PO}_{4}\right)$ distributions deep in the water column would be mainly regulated by the remineralization process of biogenic organic matter. Virtually, all of the regenerated nitrogen is converted to nitrate and remains in solution. Therefore, the surface layer of MKW, in which iron and nutrient were mainly supplied by vertical mixing during winter, tends to be iron-deficient but otherwise nutrient-replete during and after the spring bloom, resulting from faster exhaustion of iron than macronutrient by phytoplankton uptake (Fig. 5). The Kuroshio rings have no other iron supply to the surface layer, such as riverine or other lateral inputs.

The relationships between iron and Chl- $a$ concentrations in COW $(\mathrm{S}<33.3)$ were remarkably different from those in MKW (Fig. 11a and b). It appears that [D-Fe], [T-Fe] and Chl- $a$ in near surface COW are generally higher than observed in MKW. 
[T-Fe] was especially high in the range from $\sim 10$ to $25 \mathrm{nM}$ in COW (Figs. 8, 11a and b). We estimated how much of the particulate Fe ([P-Fe]=[T-Fe]-[D-Fe]) can be accounted for the Chl- $a$ alone, assuming typical carbon (C):Chl- $a$ weight ratio (50:1, Saito and Tsuda, 2003; Price, 2005) and Fe:C molar ratio (1:100,000, Sunda and Huntsman, 1995) of coastal phytoplankton. In the higher range of Chl- $a$ concentrations from 5 to $20 \mu \mathrm{g} \mathrm{l}^{-1}$, only about 3-4\% of [P-Fe] was accounted by the Chl-a (Fig. 11b). There was little relation between $[\mathrm{T}-\mathrm{Fe}]$ and $[\mathrm{D}-\mathrm{Fe}]$ in $\mathrm{COW}(\mathrm{S}<33.3)$, while there was a strong correlation between them in more saline water (\$33.3) (Fig. 11c). Using the iron data for more saline water ( $\mathrm{S} \geq 33.3$ ), including $\mathrm{MKW}$, the correlation coefficient $(\mathrm{R})$ between [T-Fe] and [D-Fe] was $0.905(\mathrm{n}=175)$ : $[\mathrm{T}-\mathrm{Fe}](\mathrm{nM})=7.459 x[\mathrm{D}-\mathrm{Fe}](\mathrm{nM})+1.802$ (Fig. 11c). In addition, the more saline water ( $\$ 33.3)$ exhibited strong correlations of both dissolved and total iron with $\mathrm{NO}_{3}+\mathrm{NO}_{2}$ concentrations $\left\{[\mathrm{D}-\mathrm{Fe}](\mathrm{nM})=0.0373 x\left[\mathrm{NO}_{3}+\mathrm{NO}_{2}\right](\mu \mathrm{M}) \quad-\quad 0.114 \quad(\mathrm{R}=0.890, \quad \mathrm{n}=178) ;\right.$ $\left.[\mathrm{T}-\mathrm{Fe}](\mathrm{nM})=0.223 x\left[\mathrm{NO}_{3}+\mathrm{NO}_{2}\right](\mu \mathrm{M})+1.180(\mathrm{R}=0.785, \mathrm{n}=179)\right\}$. There were no such linear relationships between them in the less saline water $(S<33.3)$, including COW (Fig. 12). The strong correlations of [T-Fe] with [D-Fe], of [D-Fe] with $\mathrm{NO}_{3}+\mathrm{NO}_{2}$ concentration and of [T-Fe] with $\mathrm{NO}_{3}+\mathrm{NO}_{2}$ concentration in the more saline water $(\mathrm{S} \geq 33.3)$ may suggest that $[\mathrm{T}-\mathrm{Fe}]$ and $[\mathrm{D}-\mathrm{Fe}]$ as well as macronutrients in the surface mixed layer were supplied by the upward transport during vertical mixing of oceanic water (Figs. 4, 11c and 12). On the other hand, extremely high and variable [T-Fe] in COW $(\mathrm{S}<33.3)$ probably resulted from the mainly horizontal iron input to that water type (Figs. 6, 11c and 12b). It has recently been suggested that oxidative decomposition of particulate organic matter in continental shelf sediments is likely the major source of [D-Fe] to water overlying continental and island shelves (Johnson et al., 1999; Elrod et al., 2004; Nedelec et al., 2007). In the present study, high [D-Fe] and [T-Fe] in COW may be attributed to the supply of dissolved and particulate Fe from self sediments to the overlying water at the shallow Kuril passes and along the coast of Hokkaido by vertical mixing. River inputs may be also an important source of iron to shelf waters.

\subsection{Bioavailable iron in $M K W$ and COW}

Field incubations demonstrated about a 1.75-fold increase in Chl- $a$ concentration, even after the addition of DFB (Fig. 9a). The increase can be attributed to 
intracellular iron, which was probably stored by luxury iron uptake by the phytoplankton community in iron-replete waters, probably due to the lateral iron input of COW (Sunda and Huntsman, 1995; Iwade et al., 2006; Yoshida et al., 2006). The high Fe uptake and storage capacity of phytoplankton allows them to accumulate excess Fe at high concentrations of bioavailable Fe species and to support up to 2-4 cell divisions without any additional Fe uptake (Iwade et al., 2006; Yoshida et al., 2006; Sugie et al., in submission). The intracellular Fe of the in situ phytoplankton community supported up to approximately $0.8 \mathrm{Chl}-a$ doublings [ $\log _{2}$ (maximal Chl- $a$ concentration after DFB addition/Chl- $a$ concentration at DFB addition)]. In the control with no added DFB there was a 2.5-fold increase in Chl- $a$ (1.3 Chl- $a$ doublings), probably resulting from further uptake of ambient external iron and faster macronutrient uptake than in the DFB medium (Fig. 9). Under iron-limited conditions after DFB addition in our culture experiments with coastal diatoms (Sugie et al., in submission), Chl- $a$ concentrations increased only for a few days while cell density increased for several days. The iron-limited diatoms primarily carry out the cell divisions, rather than Chl- $a$ synthesis, in expending the intracellularly stored Fe. There is a resulting reduction in the Chl- $a$ cell quota. Price (2005) has also reported that iron-limited diatoms reduce their Chl-a cell quota, increase their $\mathrm{C}: \mathrm{Chl}-a$ ratio and maintain relatively constant $\mathrm{C}: \mathrm{N}$ ratio. The ambient external iron (0.41 nM [D-Fe] and $15.7 \mathrm{nM}$ [T-Fe]) in COW supported sufficient algal growth to exhaust the macronutrients (Fig. 9b, c and d). Thus, the surface water in COW tends to be iron-replete and macronutrient-deficient during and after the spring bloom, resulting from exhaustion by phytoplankton of macronutrients before iron.

We estimated the iron concentrations that would be required by coastal diatoms, dominant phytoplankton in the Oyashio region, from the original $\mathrm{NO}_{3}+\mathrm{NO}_{2}$ concentrations (10-15 $\mu \mathrm{M}$ and $\sim 20 \mu \mathrm{M}$ in MKW and COW, respectively), cellular Fe:C molar ratio $(1: 30,000-300,000)$ of coastal diatoms determined by iron-uptake experiments with cultures (Sunda et al., 1991; Sunda and Huntsman, 1995, 1997) and Redfield ratios (C:N:P=106:16:1, Redfield et al., 1963). From a nearly linear relationship between specific growth rate and cellular Fe:C molar ratio, it has been shown that cells need only about 3-4 $\mu$ mol Fe per mol C $(\mathrm{Fe}: \mathrm{C}=1: 300,000)$ for cell maintenance at zero growth rate but they need about $35 \mu \mathrm{mol}$ Fe per mol C (Fe:C=1:30,000) to support a specific growth rate of $1.7 \mathrm{~d}^{-1}$ (Sunda and Huntsman, 
1997). The iron concentrations, which would be required to consume 10-20 $\mu \mathrm{M}$ $\mathrm{NO}_{3}+\mathrm{NO}_{2}$ in MKW and COW at cellular Fe:C molar ratios of 1:300,000 and 1:30,000, are $0.22-0.44 \mathrm{nM}$ and 2.2-4.4 $\mathrm{nM}$, respectively. However, the estimated iron concentrations at cellular Fe:C ratio of 1:30,000 are higher than [D-Fe] observed in the surface mixed layer in MKW or COW, indicating insufficient [D-Fe] to consume ambient $\mathrm{NO}_{3}+\mathrm{NO}_{2}$ in either. Therefore, it may be suggested that the original [D-Fe] in COW before the bloom was higher than the observed 0.4-0.7 $\mathrm{nM}$ in the surface layers of COW during the bloom.

It is also possible that a considerable fraction of the particulate $\mathrm{Fe}$ in $\mathrm{COW}$ was actually bioavailable. It would have had a high dissolution rate generating D-Fe from its large surface area (Kuma and Matsunaga, 1995; Yoshida et al., 2006). Iron in oxic seawater is present predominantly in the very weakly soluble and thermodynamically stable 3+ oxidation state (Kuma et al., 1996; Waite, 2001). Iron uptake by phytoplankton in seawater is dependent on the concentration of dissolved iron species (both inorganic and organic complexes), and consequently will depend on rates of desorption or dissolution of iron from particles. Therefore, phytoplankton growth might be controlled by the solubility and the dissolution rate of particulate $\mathrm{Fe}(\mathrm{III})$, that is solid Fe(III) hydroxide, since it has generally been assumed that phytoplankton assimilate dissolved iron species. The Fe(III)' solubility and dissolution of particulate $\mathrm{Fe}(\mathrm{III})$ in seawater limit the iron uptake of phytoplankton if the dissolution rate is slow in relation to the demands of the phytoplankton. Higher particulate Fe(III) concentration in seawater generally results in more bioavailable Fe(III)' because of the larger surface area of particulate Fe(III). Therefore, the high Fe(III)' $\square$ dissolution rate would induce rapid phytoplankton growth (Kuma and Matsunaga, 1995). In the present study, the most important mechanisms transporting iron to surface waters in the Oyashio region are the intrusions of iron- and nutrient-rich COW and the vertical mixing of oceanic MKW during winter and spring.

\section{Acknowledgements}

We thank the captain and crew of "Oshoro-Maru” of Hokkaido University and "Hakuho-Maru” in the Ocean Research Institute, University of Tokyo, for their help in 
sampling. We are grateful to two anonymous reviewers for helpful comments on this paper. This study was partially supported by grants for Scientific Research (No. 18201001) from the Ministry of Education, Culture, Sports, Science and Technology, Japan.

\section{References}

Abe, K., 2002. Preformed Cd and $\mathrm{PO}_{4}$ and the relationship between the two elements in the northwestern Pacific and the Okhotsk Sea. Marine Chemistry 79, 27-36.

Anderson, M.A., Morel, F.M.M., 1982. The influence of aqueous iron chemistry on the uptake of iron by the coastal diatom Thalassiosira weissflogii. Limnology and Oceanography 27, 789-813.

Bruland, K.W., Orians, K.J., Cowen, J.P., 1994. Reactive trace metals in the stratified central North Pacific. Geochimica et Cosmochimica Acta 58, 3171-3182.

Bruland, K.W., Rue, E.L., Smith, G.J., 2001. Iron and macronutrients in California coastal upwelling regimes: Implications for diatom blooms. Limnology and Oceanography 46, 1661-1674.

Campbell, P.G.C., 1995. Interactions between trace metals and aquatic organisms: A critique of the free-ion activity model. In: Tessier, A., Turner, D.R. (Eds), Metal speciation and bioavailability in aquatic systems. Wiley, New York, pp. 45-102.

Chase, Z., Johnson, K.S., Elrod, V.A., Plant, J.N., Fitzwater, S.E., Pickel, L., Sakamoto, C.M., 2005. Manganese and iron distributions off central California influenced by upwelling and shelf width. Marine Chemstry 95, 235-254.

Coale et al., 1996. A massive phytoplankton bloom induced by an ecosystem-scale iron fertilization experiment in the equatorial Pacific Ocean. Nature 383, 495-501.

de Baar, H.J.W., de Jong, J.T.M., 2001. Distributions, sources and sinks of iron seawater. In: Turner, D.R., Hunter, K.A. (Eds.), The biogeochemistry of iron in seawater. Wiley, New York, pp. 123-253.

Duce, R.A., Tindale, N.W., 1991. Atmospheric transport of iron and its deposition in the ocean. Limnology and Oceanography 36, 1715-1726.

Elrod, V.A., Berelson, W.M., Coale, K.H., Johnson, K.S., 2004. The flux of iron from continental shelf sediments: A missing source for global budgets. Geophysical 
Research Letter 31, L12307, doi:10.1029/2004GL020216.

Fitzwater, S.T., Johnson, K.S., Elrod, V.A., Ryan, J.P., Coletii, L.J., Tanner, S.J., Gordon, R.M., Chavez, F.P., 2003. Iron, nutrient and phytoplankton biomass relationships in upwelled waters of the California coastal system. Continental Shelf Research 23, 1523-1544.

Geider, R.J., La Roche, J., 1994. The role of iron in phytoplankton photosynthesis, and the potential for iron-limitation of primary productivity in the sea. Photosynthesis Research 39, 275-301.

Hanawa, K., Mitsudera, H., 1987. Variation of water system distribution in the Sanriku coastal area. Journal of the Oceanographical Society of Japan 42, 435-446.

Hudson, R.J.M., Covault, D.T., Morel, F.M.M., 1992. Investigations of iron coordination and redox reactions in seawater using ${ }^{59} \mathrm{Fe}$ radiometry and ion-pair solvent extraction of amphiphilic iron complexes. Marine Chemistry 38, 209-235.

Hutchins, D.A., DiTullio, G., Bruland, K.W., 1998. An iron mosaic in the California upwelling regime. Limnology and Oceanography 43, 1037-1054.

Hutchins, D.A., Franck, V.M., Brzezinski, M.A., Bruland, K.W., 1999. Inducing phytoplankton iron limitation in iron-replete coastal waters with a strong chelating ligand. Limnology and Oceanography 44, 1009-1018.

Iwade, S., Kuma, K., Isoda, Y., Yoshida, M., Kudo, I., Nishioka, J., Suzuki, K., 2006. Effect of high iron concentrations on iron uptake and growth of a coastal diatom Chaetoceros sociale. Aquatic Microbial Ecology 43, 177-191.

Johnson, K.S., Chavez, F.P., Friederich, G.E., 1999. Continental-shelf sediment as a primary source of iron for coastal phytoplankton. Nature 398, 697-700.

Johnson, K.S., others, 2007. Developing standards for dissolved iron in seawater. Eos, Transactions, American Geophysical Union 88(11), 131-132.

Jickells, T.D., Spokes, L.J., 2001. Atmospheric iron inputs to the oceans. In: Turner, D.R., Hunter, K.A. (Eds.), The biogeochemistry of iron in seawater. Wiley, New York, pp. 85-121.

Kono, T., Kawasaki, Y., 1997. Modification of the western subarctic water by exchange with the Okhotsk Sea. Deep-Sea Research I 44, 689-711.

Kono, T., Sato, M., A mixing analysis of the surface water in the Oyashio region and its application to the spring bloom dynamics. Deep-Sea Research II, this issue.

Kuma, K., Matsunaga, K., 1995. Availability of colloidal ferric oxides to coastal marine 
phytoplankton. Marine Biology 122, 1-11.

Kuma, K., Nishioka, J., Matsunaga, K., 1996. Controls on iron(III) hydroxide solubility in seawater: The influence of $\mathrm{pH}$ and natural organic chelators. Limnology and Oceanography 41, 396-407.

Kuma, K., Katsumoto, A., Shiga, N., Sawabe, T., Matsunaga, K., 2000. Variation of size-fractionated Fe concentrations and Fe(III) hydroxide solubilities during a spring phytoplankton bloom in Funka Bay (Japan). Marine Chemistry 71, 111-123.

Nedelec, F., Statham, P.J., Mowlem, M., 2007. Processes influencing dissolved iron distributions below the surface at the Atlantic Ocean-Celtic Sea shelf edge. Marine Chemistry 103, 156-170.

Nishioka, J., Ono, T., Saitoh, H., Nakatsuka, T., Takeda, S., Yoshimura, T., Suzuki, K., Kuma, K., Nakabayashi, S., Tsumune, D., K. Mitsudera, Johnson, K.W., Tsuda, A., 2007. Iron supply to the western subarctic Pacific: Importance of iron export from the Sea of Okhotsk. Journal of Geophysical Research 112, C10012, doi:10.1029/2006JC004055.

Obata, H., Karatani, H., Nakayama, E., 1993. Automated determination of iron in seawater by chelating resin concentration and chemiluminescence detection. Analytical Chemistry 65, 1524-1528.

Oguma, S., Ono, T., Kusaka, A., Kasai, H., Kawasaki, Y., Azumaya, T., 2008. Isotopic tracers for water masses in the coastal region of eastern Hokkaido. Journal of Oceanography 64, 525-539.

Okamoto, S., Hirawake, T., Saitoh, S., Interannual variability of the magnitude and timing of spring bloom in the Oyashio region. Deep-Sea Research II, this issue.

Redfield, A.C., Ketchum, B.H., Richards, F.A., 1963. The influence of organisms on the composition of seawater. In: Hill, M.N. (Ed), The Sea, 2. Wiley, New York, pp. 26-77.

Price, N.M., 2005. The elemental stoichiometry and composition of an iron-limited diatom. Limnology and Oceanography 50, 1159-1171.

Saito, H., Tsuda, A., 2003. Influence of light intensity on diatom physiology and nutrient dynamics in the Oyashio region. Progress in Oceanography 57, 251-263.

Saitoh, Y., Kuma, K., Isoda, Y., Kuroda, H., Matsuura, H., Wagawa, T., Takata, H., Kobayashi, N., Nagao, S., Nakatsuka, T., 2008. Processes influencing iron distribution in the coastal waters of the Tsugaru Strait, Japan. Journal of 
Oceanography 64, 815-830.

Sato, M., Kono, T., Mixing process of the Oyashio Water from the sequential observation in spring 2007. Dee-Sea Research II, this issue.

Shaked, Y., Kutsuka, A.B., Morel, F.M.M., 2005. A general kinetic model for iron acquisition by eukaryotic phytoplankton. Limnology and Oceanography 50, 872-882.

Stumm,W., Morgan, J.J., 1996. Aquatic chemistry, 3rd edn. Wiley-Interscience, NewYork

Sugie, K., Kuma, K., Fujita, S., Nakayama, Y., Ikeda, T. Nutrient and diatom dynamics during winter and spring in the Oyashio region of the western subarctic Pacific Ocean. Dee-Sea Research II, this issue.

Sugie, K., Kuma, K., Fujita, S., Ushizaka, S., Suzuki, K., Ikeda, T. Growth of coastal diatoms in unialgal culture experiments and an in situ phytoplankton community by intracellularly stored Fe. In submission.

Sunda, W.G., Swift, D.G., Huntsman, S.A., 1991. Low iron requirement for growth in oceanic phytoplankton. Nature 351, 55-57.

Sunda, W.G., Huntsman, S.A., 1995. Iron uptake and growth limitation in oceanic and coastal phytoplankton. Marine Chemistry 50, 189-206.

Sunda, W.G., Huntsman, S.A., 1997. Interrelated influence of iron, light and cell size on marine phytoplankton growth. Nature 390, 389-392.

Sunda, W.G., 2001. Bioavailability and bioaccumulation of iron in the sea. In: Turner, D.R., Hunter, K.A. (Eds.), The biogeochemistry of iron in seawater. Wiley, New York, pp. 41-84.

Suzuki, R., Ishimaru, T., 1990. An improved method for the determination of phytoplankton chlorophyll using $\mathrm{N}, \mathrm{N}$-dimethylformamide. Journal of Oceanography 46, 190-194.

Takata, H., Kuma, K., Iwade, S., Yamajyoh, Y., Yamaguchi, A., Takagi, S., Sakaoka, K., Yamashita, Y., Tanoue, E., Midorikawa, T., Kimura, K., Nishioka, J., 2004. Spatial variability of iron in the surface water of the northwestern North Pacific Ocean. Marine Chemistry 86, 139-157.

Takata, H., Kuma, K., Iwade, S., Isoda, Y., Kuroda, H., Senjyu, T., 2005. Comparative vertical distributions of iron in the Japan Sea, the Bering Sea and the western North Pacific Ocean. Journal of Geophysical Research 110, C07004, 
doi:10.1029/2004J002783.

Takata, H., Kuma, K., Saitoh, Y., Chikira, M., Saitoh, S., Isoda, Y., Takagi, S., Sakaoka, K., 2006. Comparing the vertical distribution of iron in the eastern and western North Pacific Ocean. Geophysical Research Letters 33, L02613, doi:10.1029/2005GL024538.

Takata, H., Kuma, K., Isoda, Y., Otozaka, S., Senjyu, T., Minagawa, M., 2008. Iron in the Japan Sea and its implications for the physical processes in deep water. Geophysical Research Letters 35, L02606, doi:10.1029/2007GL031794.

Uehara, K., Miyake, H., Okazaki, M., 1997. Characteristics of the flows in the Oyashio area off Cape Erimo, Hokkaido, Japan. Journal of Oceanography 53, 93-103.

Waite, T.D., 2001. Thermodynamics of the iron system in seawater. In: Turner, D.R., Hunter, K.A. (Eds.), The biogeochemistry of iron in seawater. Wiley, New York, pp. 291-342.

Wells, M.L., Price, N.M., Bruland, K.W., 1994. Iron limitation and the cyanobacterium Synechococcus in equatorial Pacific waters. Limnology and Oceanography 39, 1481-1486.

Wells, M.L., 1999. Manipulating iron availability in nearshore waters. Limnology and Oceanography 44, 1002-1008.

Wu, J., Boyle, E., 2002. Iron in the Sargasso Sea: Implications for the processes controlling dissolved Fe distribution in the ocean. Global Biogeochemical Cycles 16(4), 1086, doi:10.1029/2001GB001453.

Yasuda, I., Okuda, K., Hirai, M., 1992. Evolution of a Kuroshio warm-core ring -variability of the hydrographic structure. Deep-Sea Research 39, Suppl. 1, S131-S161.

Yoshida, M., Kuma, K., Iwade, S., Isoda, Y., Takata, H., Yamada, M., 2006. Effect of aging time on the availability of freshly precipitated ferric hydroxide to coastal marine diatoms. Marine Biology 149, 379-392.

Figure captions

Fig. 1. Sampling location (Stn A5 on A-line: $42^{\circ} 00^{\prime} \mathrm{N}, 145^{\circ} 15^{\prime} \mathrm{E}$ ) in the Oyashio region (northwestern North Pacific) during 9 March-1 May 2007. 
Fig. 2. Contoured time series of water column temperature (a) and salinity (b) before and during the spring phytoplankton bloom (9 March to 1 May 2007) at Stn A5.

Fig. 3. Contoured time series of water column Chl-a (a), $\mathrm{NO}_{3}+\mathrm{NO}_{2}$ (b), D-Fe (c) and T-Fe (d) concentrations before and during the spring phytoplankton bloom (9 March to 1 May 2007) at Stn A5.

Fig. 4. Vertical distributions of D-Fe (a), T-Fe (b), Chl-a (c), $\mathrm{NO}_{3}+\mathrm{NO}_{2}$ (d), $\mathrm{PO}_{4}$ (e) and $\mathrm{Si}(\mathrm{OH})_{4}$ concentrations (f) in the warmer, more saline water before the spring phytoplankton bloom (10 and 14 March 2007) at Stn A5.

Fig. 5. Vertical distributions of D-Fe (a), T-Fe (b), Chl- $a$ (c), $\mathrm{NO}_{3}+\mathrm{NO}_{2}$ (d), $\mathrm{PO}_{4}$ (e) and $\mathrm{Si}(\mathrm{OH})_{4}$ concentrations (f) in the warmer, more saline water during the spring phytoplankton bloom (17 and 19 April 2007) at Stn A5.

Fig. 6. Vertical distributions of D-Fe (a), T-Fe (b), Chl- $a$ (c), $\mathrm{NO}_{3}+\mathrm{NO}_{2}$ (d), $\mathrm{PO}_{4}$ (e) and $\mathrm{Si}(\mathrm{OH})_{4}$ concentrations (f) in the colder water during the spring phytoplankton bloom (6 and 7 April 2007) at Stn A5.

Fig. 7. Vertical distributions of D-Fe (a), T-Fe (b), Chl- $a$ (c), $\mathrm{NO}_{3}+\mathrm{NO}_{2}$ (d), $\mathrm{PO}_{4}$ (e) and $\mathrm{Si}(\mathrm{OH})_{4}$ concentrations (f) in the colder water during the spring phytoplankton bloom (23 and 25 April 2007) at Stn A5.

Fig. 8. Seasonal variations of averaged salinity (a), $\mathrm{NO}_{3}+\mathrm{NO}_{2}$ and Chl- $a$ concentrations (b) and D-Fe and T-Fe concentrations (c) in the upper 10-20 m before and during the spring phytoplankton bloom (9 March to 1 May 2007) at Stn A5.

Fig. 9. Changes in Chl- $a$ concentration (a) and nutrient concentrations $\left[\mathrm{NO}_{3}+\mathrm{NO}_{2}\right.$ (b), $\mathrm{PO}_{4}$ (c) and $\mathrm{Si}(\mathrm{OH})_{4}(\mathrm{~d})$ ] for $0,1,3$ and/or 5 d shipboard incubations of DFB treated seawater (only DFB addition with a final concentration of $1 \mu \mathrm{mol} \mathrm{l}^{-1}$ ) and of control incubations (without any added iron, nutrient or DFB). Data for Chl- $a$ and nutrient concentrations are means $(n=3)$ of triplicate culture experiments. Error bars represent 
mean \pm 1 SD where they are larger than the symbol diameter.

Fig. 10. Relationships between Chl- $a$ and nutrients $\left[\mathrm{NO}_{3}+\mathrm{NO}_{2}(\mathrm{a}), \mathrm{PO}_{4}(\mathrm{~b})\right.$ and $\mathrm{Si}(\mathrm{OH})_{4}$ (c)] concentrations in three salinity ranges: $\mathrm{S}<33.3$. $\mathrm{S}=33.3-33.5$ and $\mathrm{S}>33.5$

Fig. 11. Relationships between Chl- $a$ and iron [D-Fe (a) and T-Fe (b)] concentrations and between $\mathrm{D}-\mathrm{Fe}$ and $\mathrm{T}-\mathrm{Fe}$ concentrations (c) in three salinity ranges: $\mathrm{S}<33.3$, $\mathrm{S}=33.3-33.5$ and $\mathrm{S}>33.5$

Fig. 12. Relationships between $\mathrm{NO}_{3}+\mathrm{NO}_{2}$ and iron [D-Fe (a) and T-Fe (b)] concentrations and between D-Fe and T-Fe concentrations (c) in two salinity ranges: $\mathrm{S}<33.3$ and $\mathrm{S} \geq 33.3$ 
Fig.1

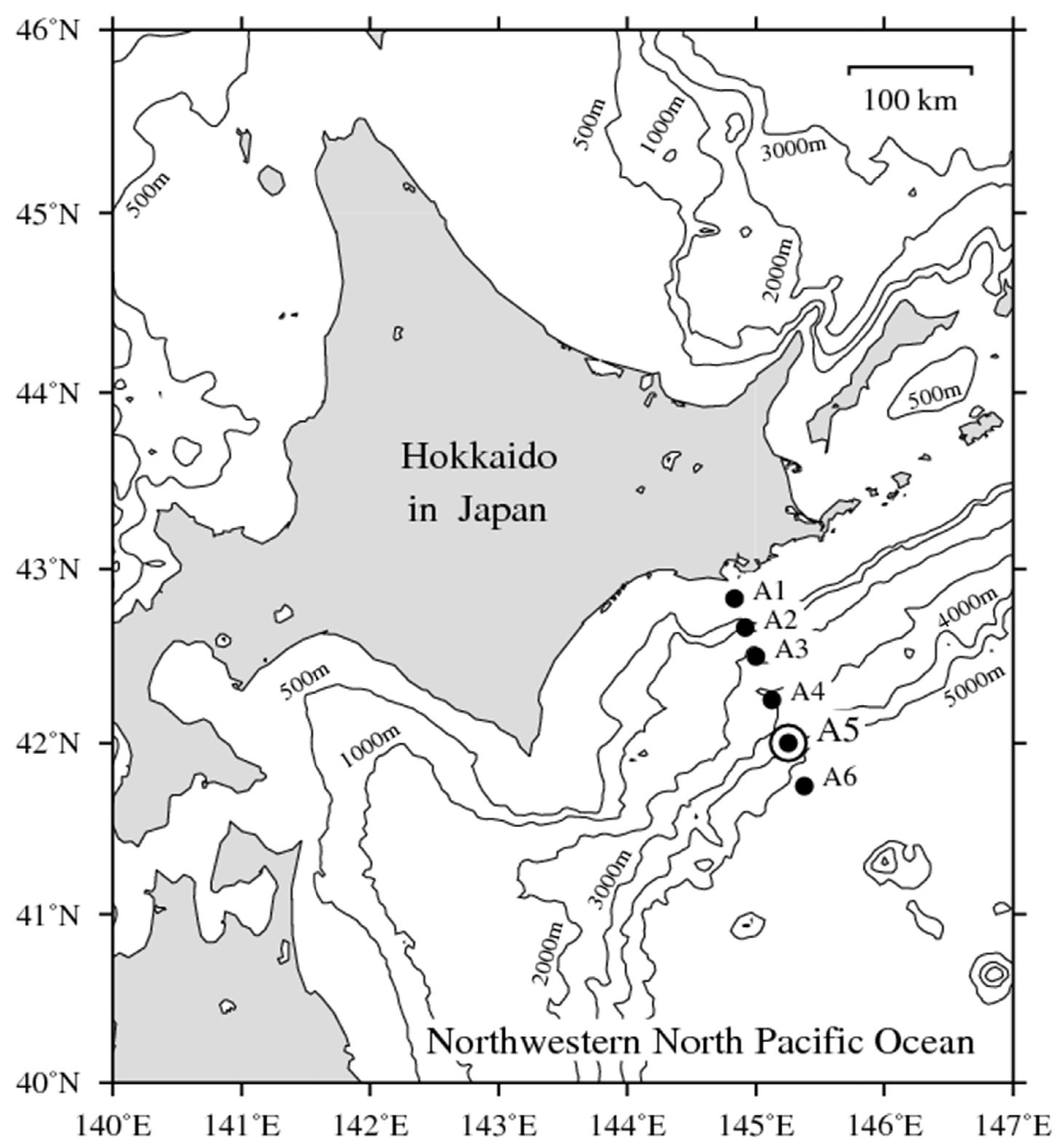


Fig.2
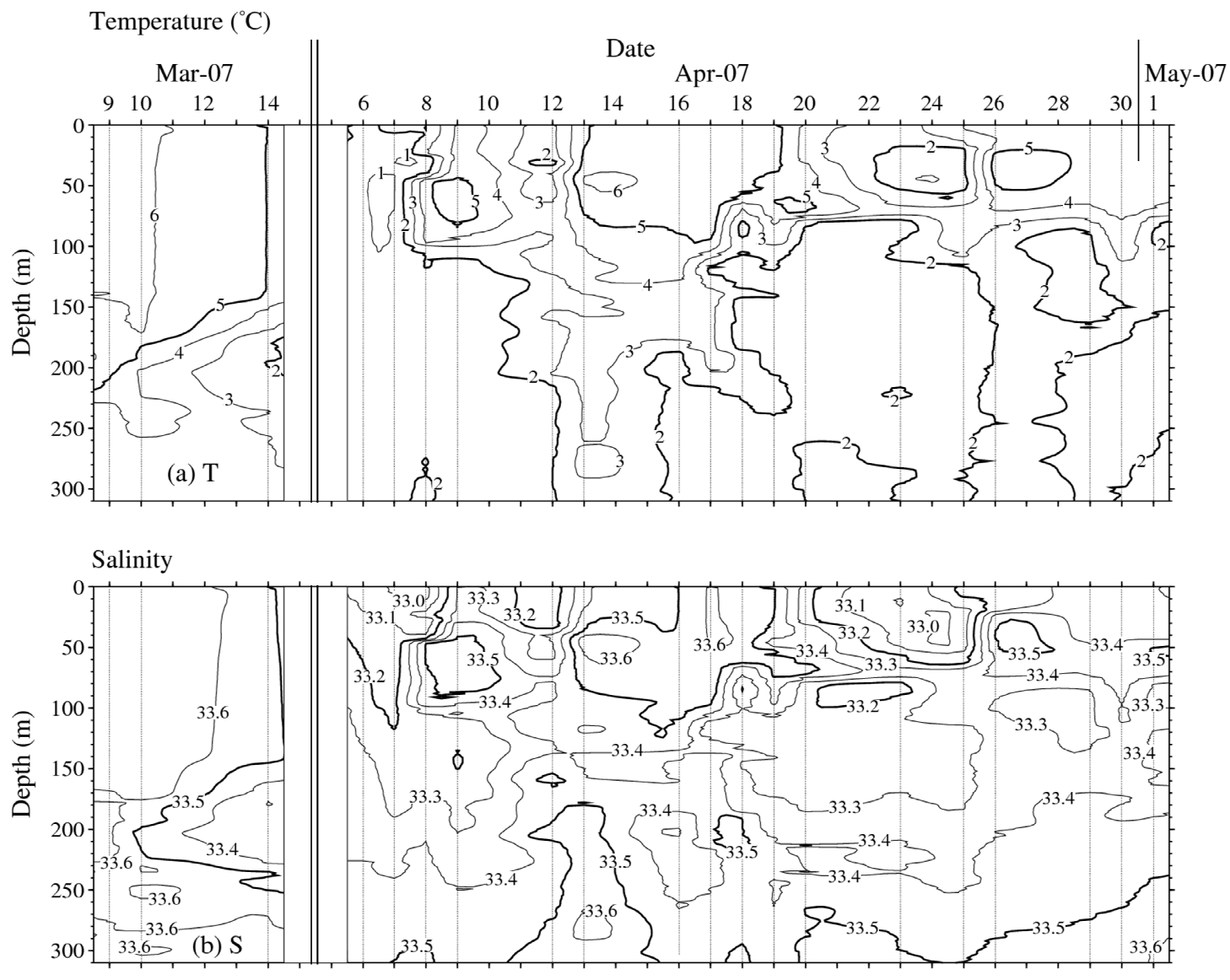
Fig.3
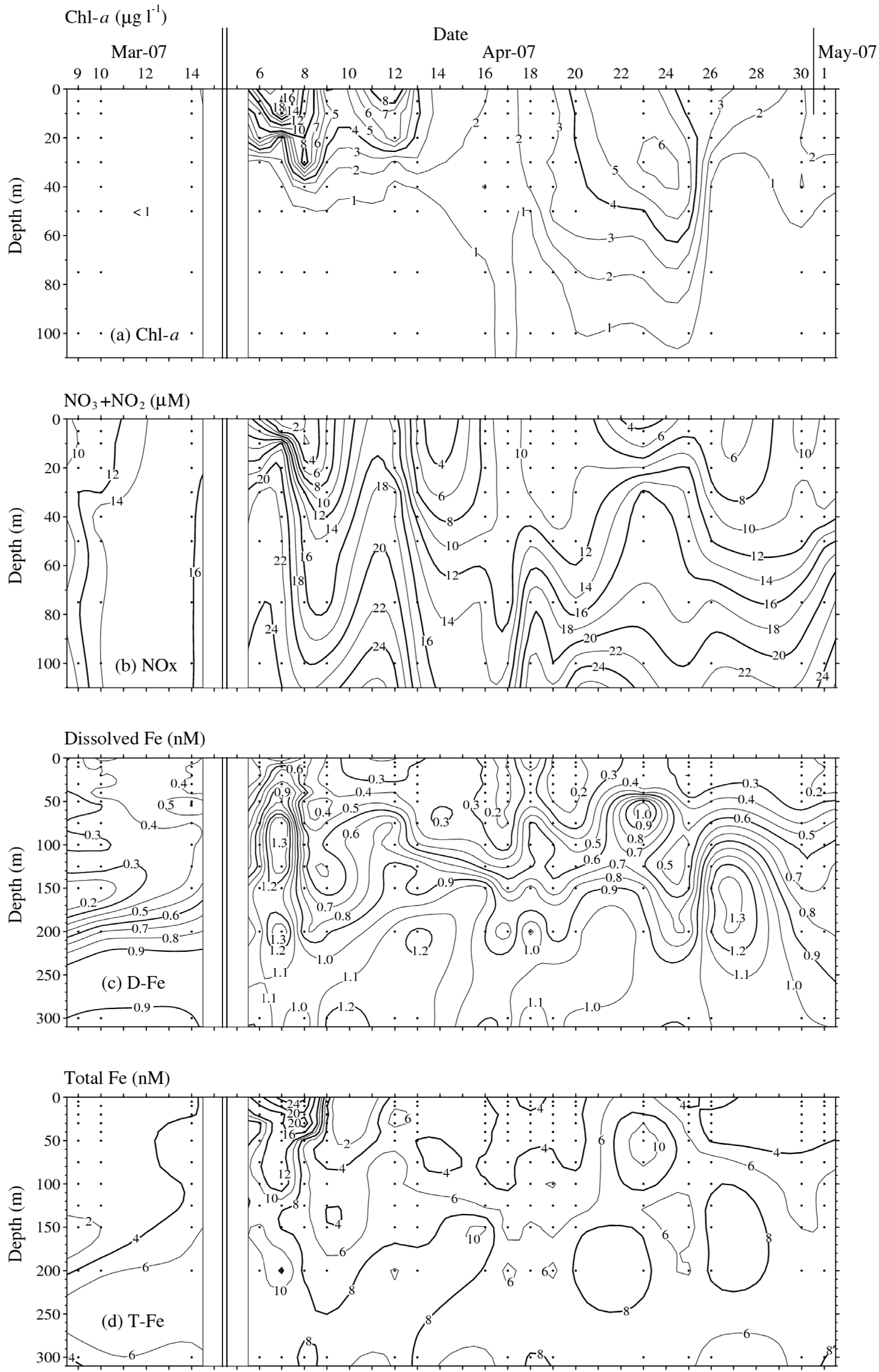
Fig. 4
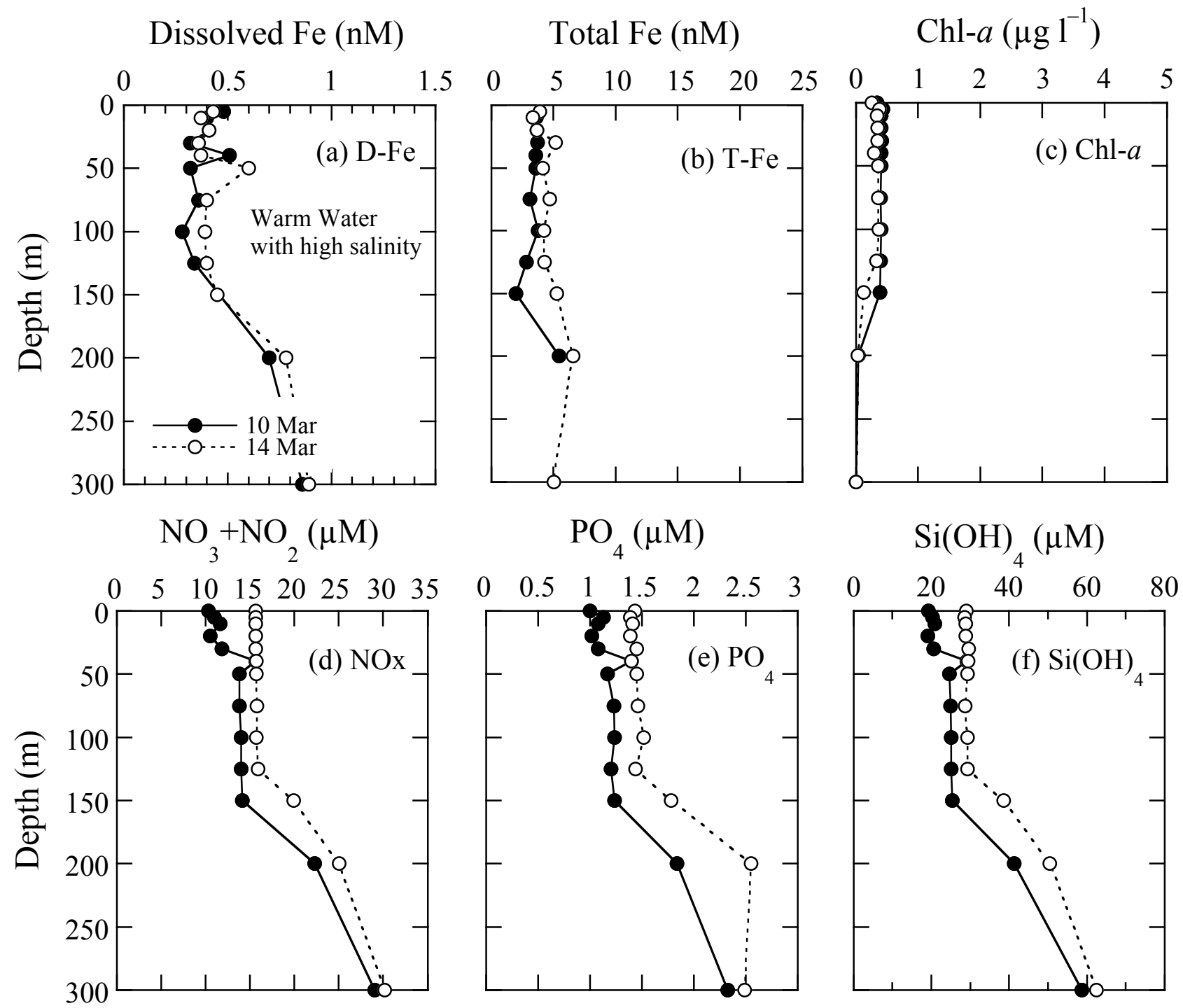
Fig. 5
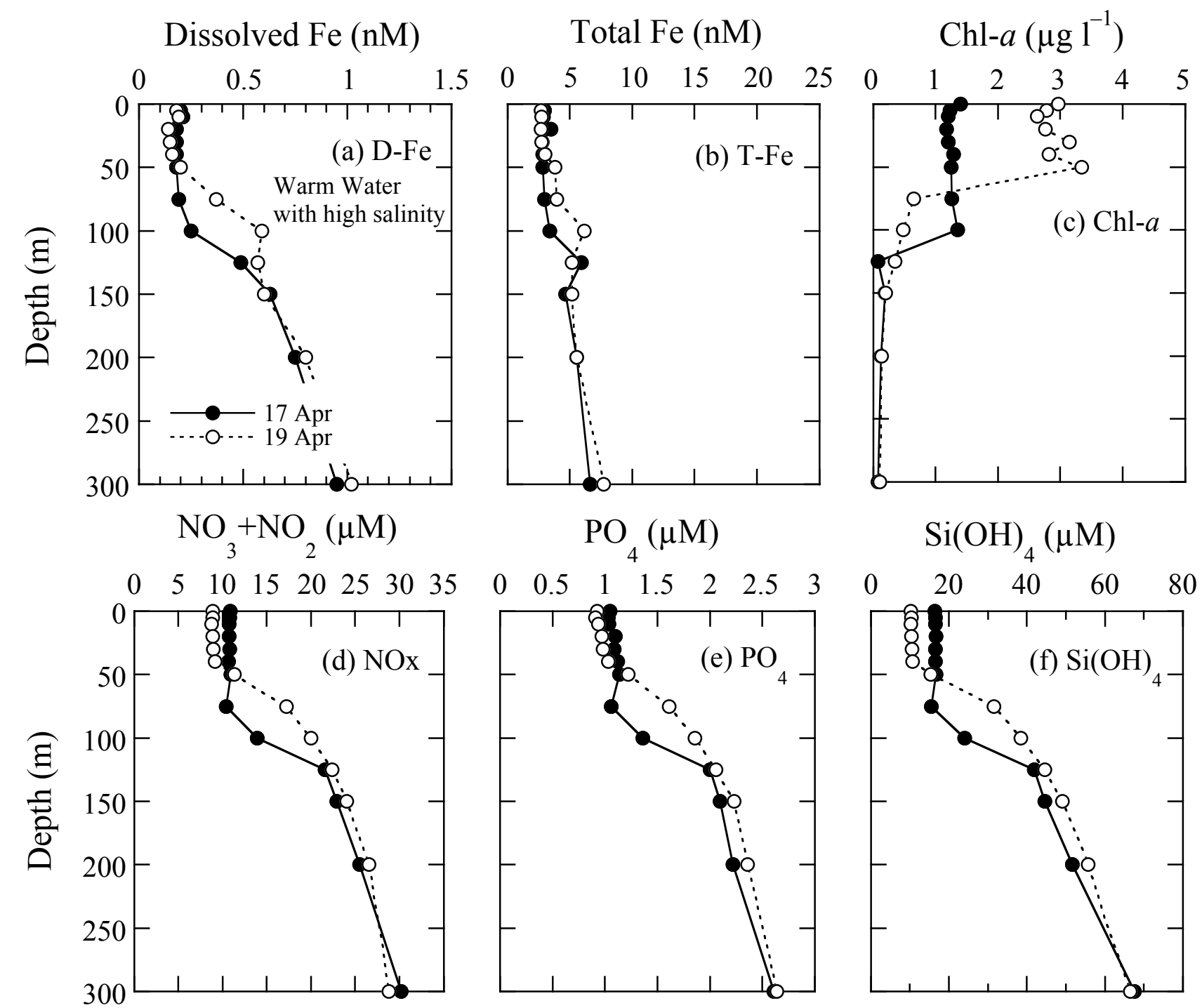
Fig. 6
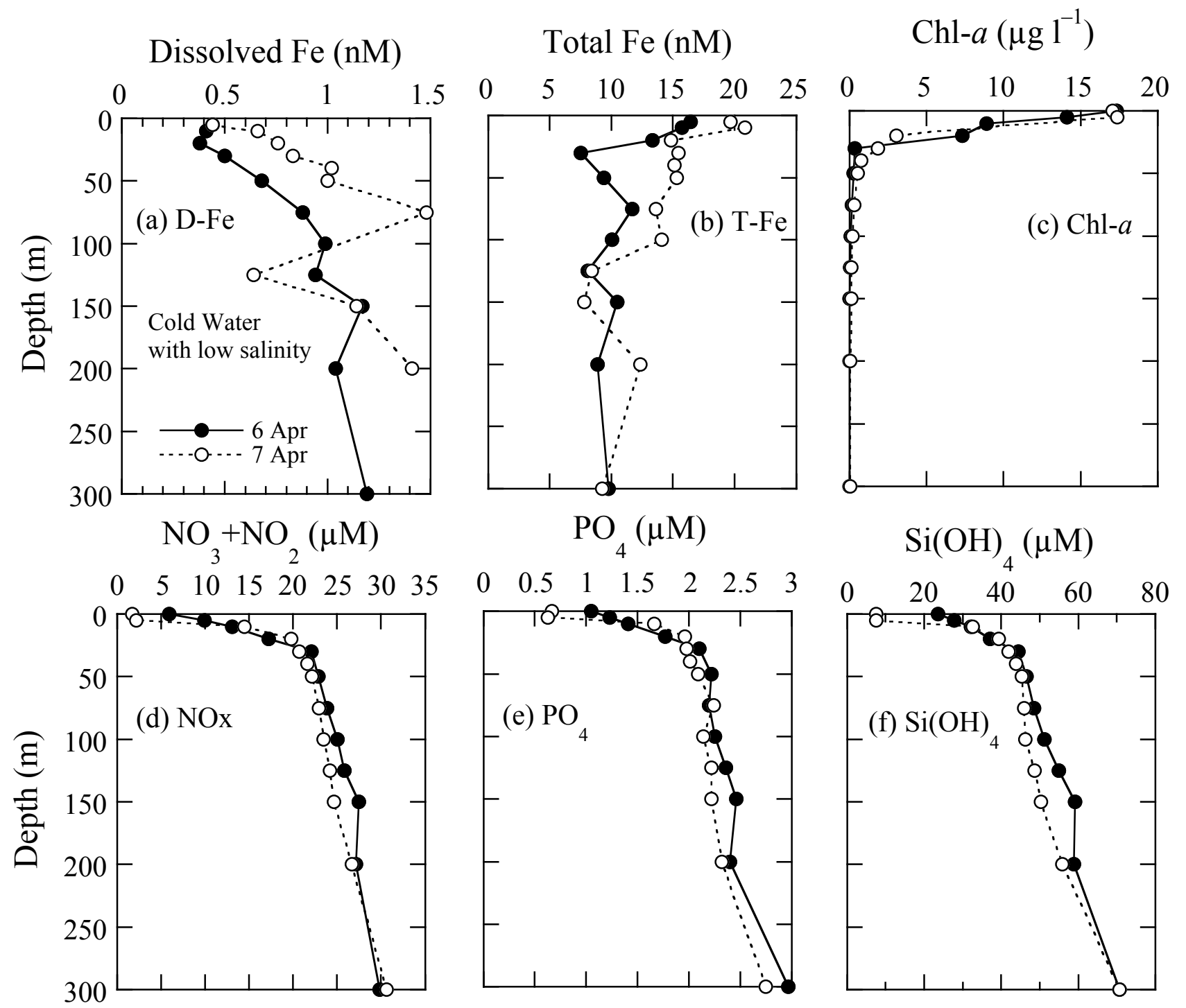
Fig. 7

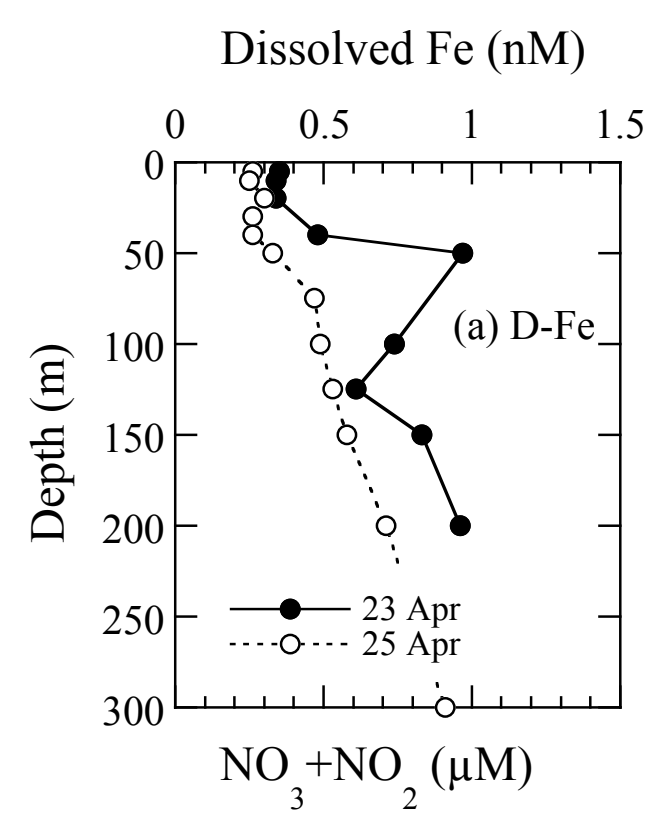

Total Fe (nM)
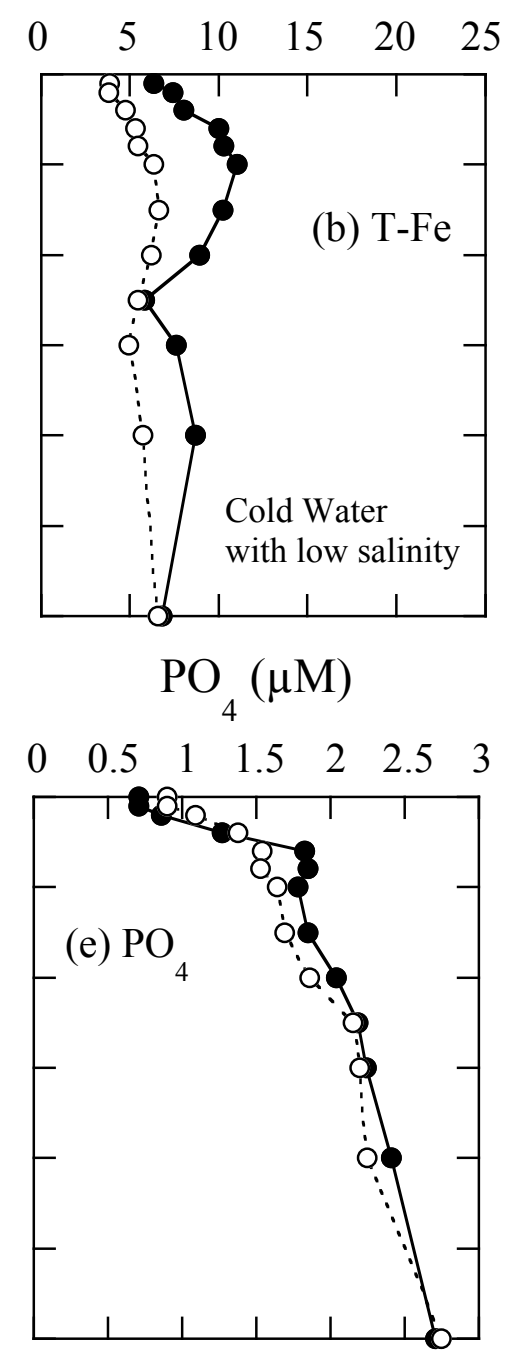

Chl- $a\left(\mu \mathrm{g} \mathrm{l}^{-1}\right)$
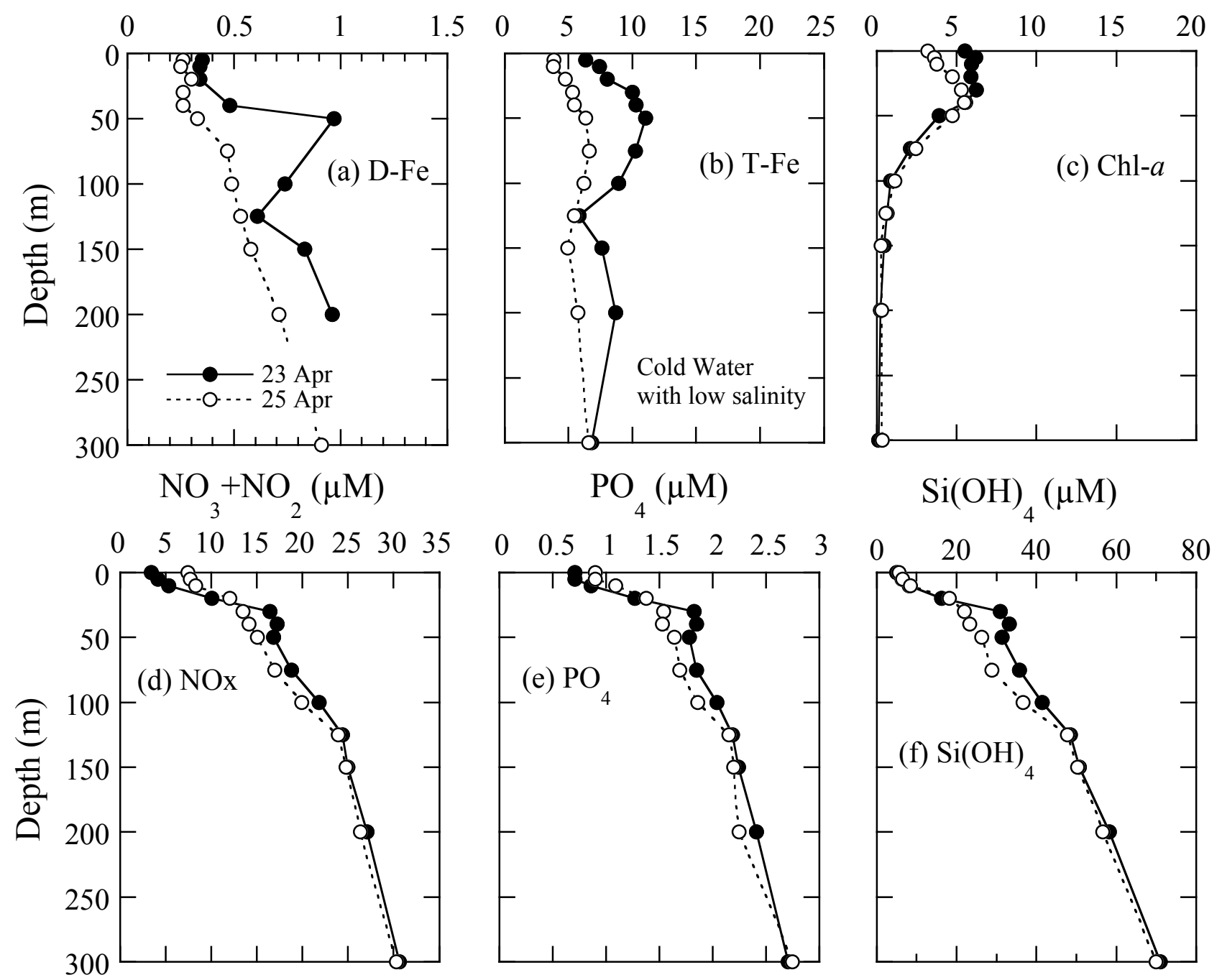
Fig. 8

\section{Date}
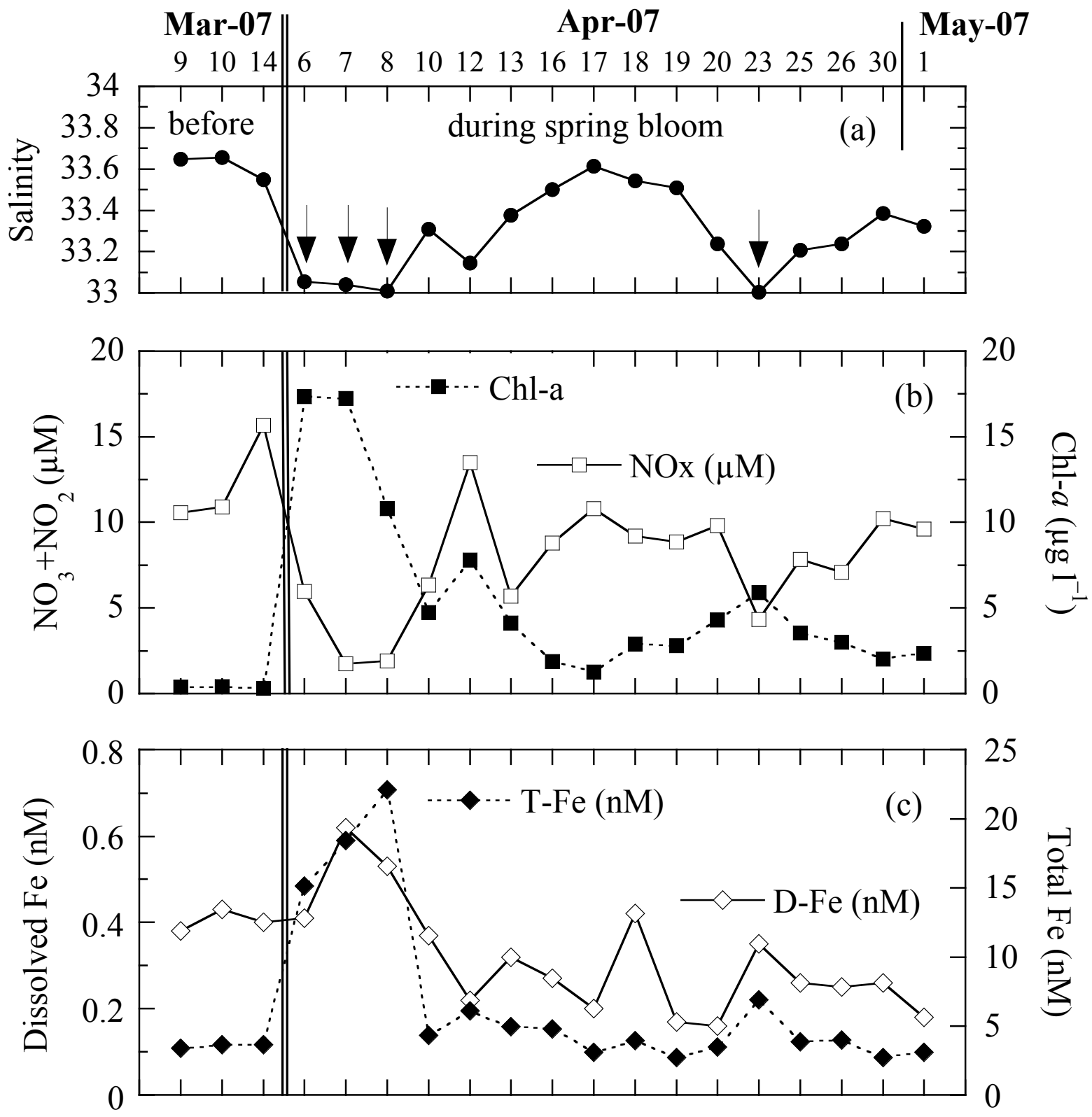

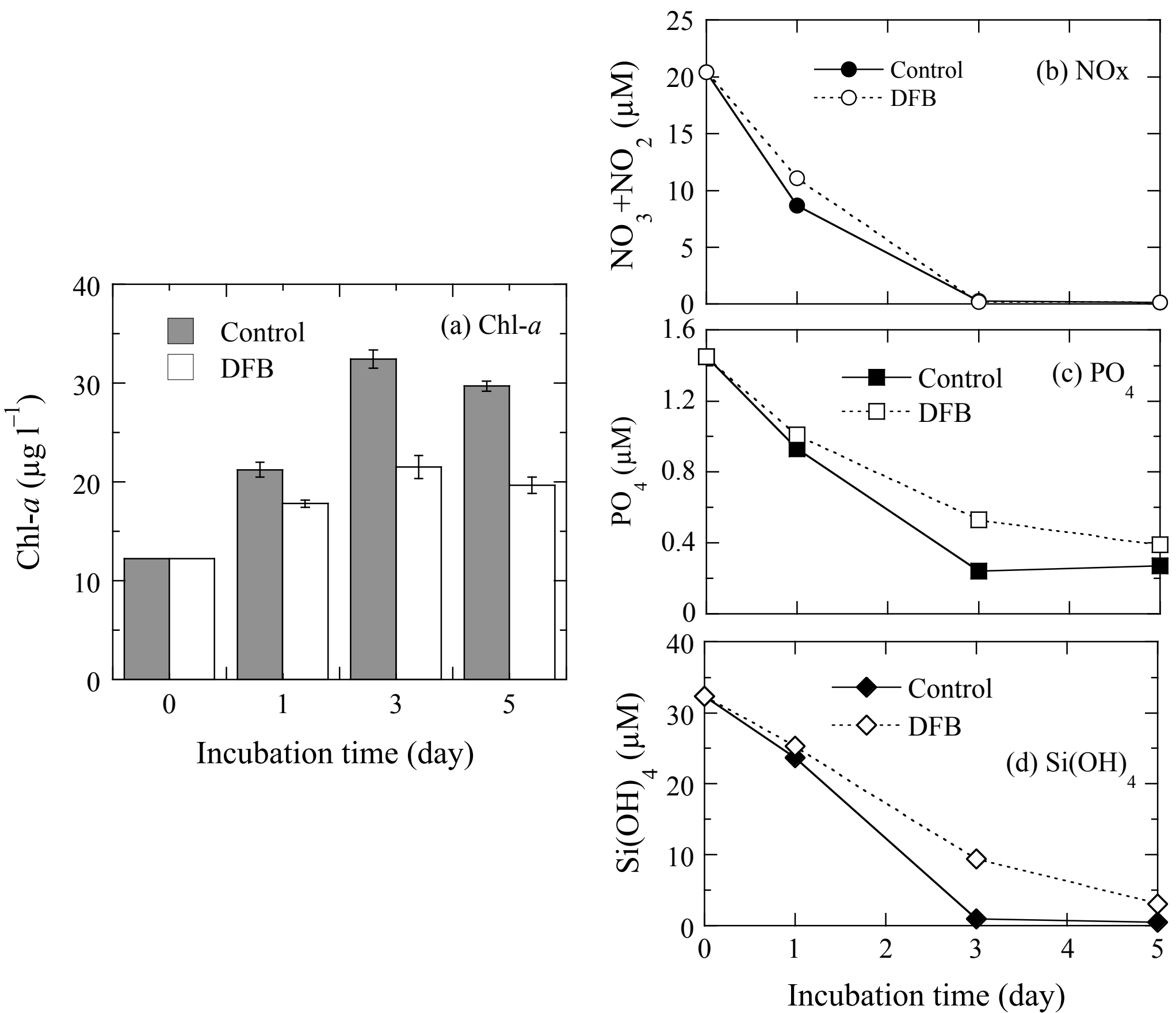
Fig. 10
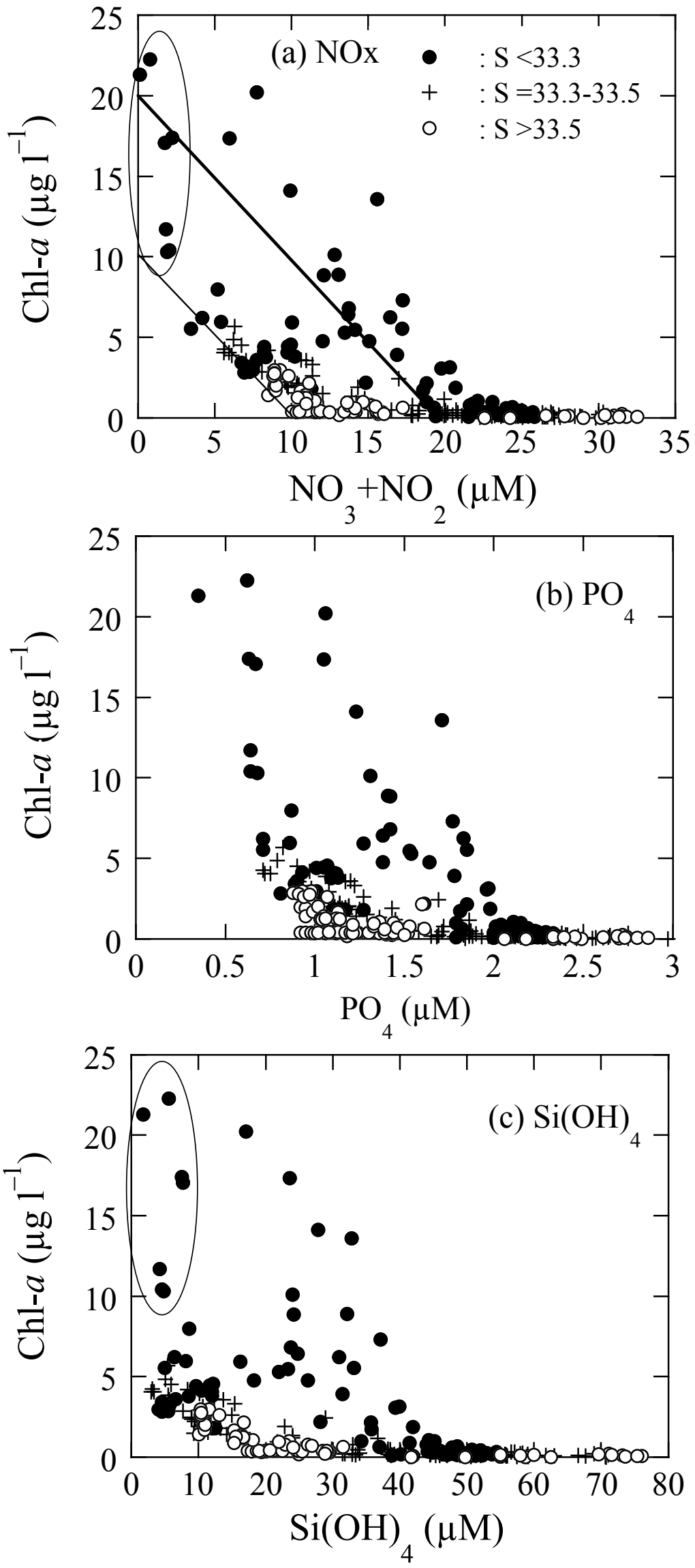
Fig. 11
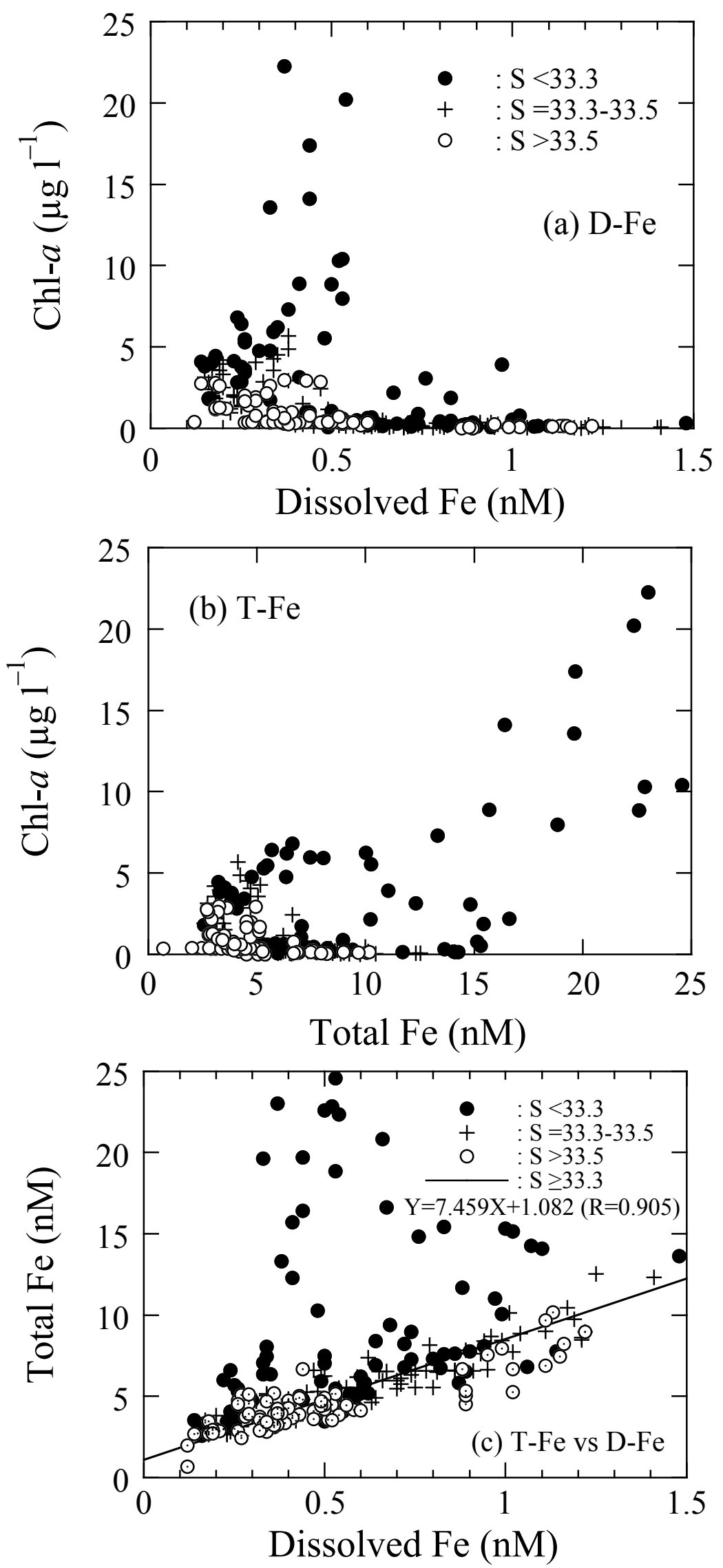
Fig. 12
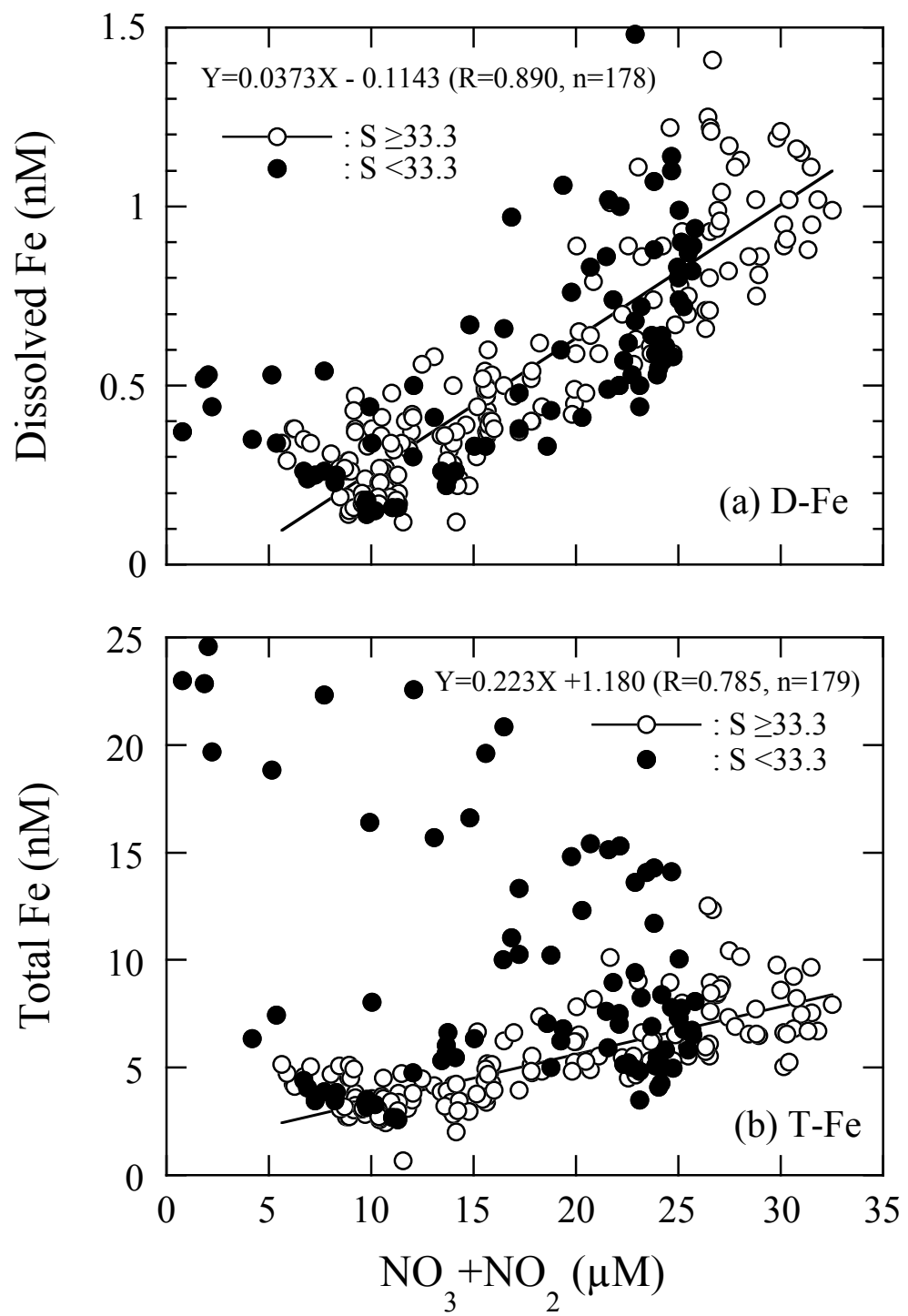